\title{
Nothing but Gold. Complexities in Terms of Non-difference and Identity. Part 3. Permanence, Properties Plexuses and Subtleties in Mutual Exclusion
}

\author{
Alberto Anrò ${ }^{1}$ iD
}

Accepted: 17 November 2021/Published online: 21 February 2022

(C) The Author(s) 2022

\begin{abstract}
This paper investigates Vācaspati Miśra's remarkably complex argumentative architecture in support of non-difference by means of a microsimulation model, the classical gold-crown case. A full range of positions, including instantaneism, transformative continuum, indeterminate common basis reference, difference and non-difference coordination, etc., is put under the scrutiny of the Vācaspati Miśra's dialectic effort. The possibility of coexistence of multiple properties with a single referent is then formally explored. The analysis is carried out in compliance with the 'Navya-Nyāya Formal Language' extensional set-based approach and its non-predicative, and variables free, relational syntax. Repeatable modules and structures of reasoning are identified and designed in the form of hypothesis frameworks, axioms and theorems to allow more accurate inferences, in particular regarding transformation and permanence, together with possible or impossible plexuses of properties. Identity and difference qua mutual absence are thoroughly defined with the aid of these formal tools, which conjointly might cast new light on the heuristic and expressive power of Navya-Nyāya logic, as well as on the theoretical potentialities of the non-dualistic account.
\end{abstract}

Keywords Transformation · Permanence $\cdot$ Existence $\cdot$ Co-existence . Difference $\cdot$ Non-difference

In the first two parts of the present project (P1\&P2), in compliance with 'NavyaNyāya Formal Language' (NL; cf. Anrò 2022), the necessary logical foundations have been laid down in order to carry out the analysis of the section of Vācaspati Miśra's (VM) Bhāmatī (VM-B) that Bhāskararāya, in his Prakāśa auto-commentary

Alberto Anrò

alberto.anro@unito.it

1 University of Turin, Turin, Italy 
to Varivasyārahasya, calls hätaka-makuța-grantha ('The golden crown section'; cf. P1. fn.1, 10; and VVR-P 3, 2000, p. 5). The pivotal role played by the notion of coreferentiality (sāmānādhikaranya; $N$ ) in defining the relation of non-difference (abheda; z) has been also shown. This latter, in turn, can never be reduced to equivalence (tulyatva; $E$ ), equality (samaniyatatva; $Q$ ), or identity $(I)$, sensu stricto. In this third part the issue concerning permanence, transformation and difference is tackled. A new translation of VM-B is proposed and framed with the intention of highlighting its argumentative structure, expanding the logical and onto-gnoseological aspects there implied. NL formulae, for their part, could be considered as a form of translation themselves. The numbering of these formulae will refer to the first two parts of this project. Regarding, on the one hand, the relation between Navya-Nyāya (NN) and NL as hermeneutical devices, and, on the other, the relation between NL and VM's vedāntin account as object of the former, refer to P1 \& P2 and (Anrò 2022).

\section{Existence and Temporality (1)}

VM opens his reasoning with the claim that there is talk of "two kinds of permanence (nityatā): immutable (kütastha) one and permanence of 'what transforms' (parināmin)", just to immediately state that this latter cannot be said to be ultimately real (pāramārthika). How and why does VM come to this conclusion? Most importantly, what is its overall purport? VM's strategy is sharp and lucid. In the hypothesis, he first asks, transformation would take place:

"in which manner [would it do]? In whole (sarvātman) or in part (ekadeśa)? [a] In the case of a transformation in toto, how [could] it not [generate a] contradiction (vyāhati) with 'what [this transforming whole is supposed] to be' (tattva) (cf. §2.1)? [b] [Otherwise], in the case of a partial transformation [only], is [this evolving] part distinct (bhinna) or non-distinct (abhinna) from that [which, on the contrary, in toto does not evolve]? If there would be a distinction, how [could] the transformation of that [subject which in toto does not evolve and which is distinct from what evolves, be possibly conceived]? When [something] distinct (anya) is transforming, [everything else, qua] other (anya) [from the former, undoubtedly] does not transform, lest [an undue] 'over-application' (atiprasanga) [of the concept of transformation be erroneously performed] (cf. \$2.2.1). Or, given the case of non-distinction, how [to avoid falling back into the situation of] a transformation in whole (cf. [a] and $\S 2.2 .2) ?^{1}$

\footnotetext{
1 VM-B (2018, p. 72): pare hi dvaȳ̄m nityatām āhuh kūṭasthanityatā-parināminityatām ca | [...] parin̄āminityatā hi na pāramārthikī|. [...] tathā hi tatsarvātmanā vā parinamate ekadeśena vā? sarvātmanā parị̄āme kathạ̣ na tattvavyāhatiḥ? ekadeśaparịnāme vā sa ekadeśas tato bhinno vā abhinno $v \bar{a}$ ? bhinnaś cet katham tasya pariṇāmaḥ? na hy anyasmin parinamamāne 'nyah parinamati, atiprasangāt | abhede vā katham na sarvātmanā parin̄āmah??
} 
For the purpose of clarification of VM's implicit premises, let us first consider the primitive property, sattā (Being; $s_{t}$ ) as the most comprehensive genus $(j \bar{a} t i) .{ }^{2}$ By the Axiom of Possession (TvN, Tad-vattva-Nyāya; cf. P1.§3), 'What is' is forcefully an occurrence of sattā, since 'What is not' is conversely different from 'What is [generically] in possession of Being': asat sattāvadbhinnam (NK, p. 102). This perspective assumes tonality of more complexity in considering existence (astitva) as the relation between sattā and temporality ( $\left.k a \overline{l a t v} a ; t_{t}\right)$. Indeed, what exists is an occurrence of the Being property in relation to time (kālatvāvacchinna-sattā: $\left.t_{t}\right\urcorner s_{t}$ ), whereas what does not exist has no relation with time (kālatvānavacchinna-sattā: $\nexists$ $\left.\left(t_{t}\right\urcorner s_{t}\right)$ ). Consequently, a particular qualified cognition (viśișta-jñāna, V; P1.§§3-4) such as the following will be generated: $\left.t^{1}\right\urcorner s^{1}$, i.e., 'A generic being $s^{1}$ (for $s^{1} \in\left|s_{t}\right|$ $=\mathrm{S}$ ) is limited by a particular temporal coordinate $t^{1}$ (for $t^{l} \in\left|t_{t}\right|=\mathrm{T}$ )'. This assertion is assumed to be true due to the fact that $s^{1}$ is said to be actually in relation to time $t^{1} .3$ Conversely, the analogous assertion $\left.* t^{2}\right\urcorner s^{1}$ is false $(*)$, because $s^{1}$, existing at

\begin{abstract}
${ }^{2}$ VM himself makes explicit use of the notion of sattā a little further on: cf. VM-B (2018, p. 73) and P4.§3. According to VM (cf. infra fn. 33) a proper occurrence of sattā is vastu, 'a being' (cf. also fn. 4), and interestingly also 'a knowable' (cf. NK, p. 728: vastutvam prameyatvam). In the Nyāya-Vaiśeșika theoretical framework, regarding the universal (jāti) sattā (Being) as the most comprehensive generality (parasamānya) occurring by inherence (samavāya) in substances (dravya), qualities (guna), and actions (karman), cf. NK, pp. 944-945: sattā-dravyagunakarmasamavetā | iyam ca vaiśeșikamate parasattā parasamānyam vā ity ucyate dravyagunakarma-vṛttiś ceti bodhyam | [...] dravyādi-trika-vartin̄̄ sattākhyā jätih iti |. Regarding the equivalence between sattā and sattva, cf. NK, p. 946: sattvamsattāśabdavadasyārtho 'nusamdheyah |. Cf. also KŚ (1951, p. 18): "Generality is of two kinds-the more comprehensive and the less comprehensive [...]. In common speech sāmānya means a common feature; but, in the technical language of Nyāya, it is equivalent to jāti and is understood to stand for a generic feature which inheres in all the individuals constituting a class [...]". NK: 1009-1012: sāmānya; Potter (1977, pp. 133-135): "[sāmānya] universal". Grimes (1996, p. 271): "sāmānya-generality; class; universal feature; concept; genus". Cf. VS 1.2.7-10 (1923, pp. 43-46). Regarding jāti, cf. NK, pp. 291293; Jha (2001, p. 302): "generic character/universal"; Phillips (2012, p. 165): "universal, natural kind, a property occurring in more than a single instance or locus"; Potter (1977, p. 134): "natural kind"; Ingalls (1951, p. 40): "generic character". In the meaning of 'natural kind' and 'generic character', I adopt here the Latin term 'genus', for the sake of clarity and brevity.
\end{abstract}

3 NK: 109: astitvam-kālasambandhitvam |; NK, p. 100: as-(dhatuh) kālasambandhaviśeșah|; NK, p. 102: asat_yat kālasāmānyāsambandhi tat |. Matilal (1968, p. 72 and fn. 4): "The notion of locus is extended in later Nyāya to include temporal locus as well. A physical body is considered in Navya-Nyāya as having a temporal stretch just as it has a spatial stretch. [...] The portion of time covered by the duration of some physical body may be regarded as 'time' in a secondary sense (kālopädhi). [...] Such time segments constitute the temporal span of ordinary objects. Thus, a mango may be green at time $t_{1}$ and red at time $t_{2}$, when it is ripe. [...] ' $x$ [the mango] as limited by time $t_{1}$ is a locus of $y$ [green colour]' [...] ' $x$ as limited by time $t_{2}$ is a locus of $\sim y$ ' [absence of green colour]"; "[...] utpattikālāvacchinno ghațo gandhābhāvavān ('A pot as limited by its production has no smell'). Also sentences like 'idānīm parvate vahnir nāsti' ('There is fire at this time on the mountain') are analysed as etatkālāvacchinnah parvate vahnyabhāvavān ('The mountain as limited by this moment has no fire')". Matilal (1968, p. 43 and fn. 34): "The postulate of temporal svarūpa relation can be justified by the following empirical considerations. Everything occurs in time. Time has thus been conceived as the locus of everything in the universe. [...] Our usual practice is to refer to the imposed divisions or calibrations (upädhi) of Time, and to connect an entity to one calibration or another", "janyānām janakaḥ kālo jagatām āśrayo matah, Viśvanātha, Bhāṣāpariccheda, verse 45b". TrS (1951, pp. 70-71): "The common-sense view of men connects the concepts of now (idānīm) with the sun's motion (süryaparispanda), brought into relation with the thing denoted by the word collocated with idānīm in expressions like idānìn ghatah. The sun's motion is directly related only with the sun, such direct relation being inherence (samavāya) in this case. A jar can be related with the sun's motion only through some indirect relation. [...] The simplest form of indirect relation that may be conceived of in this case is "contact with the thing which is in contact with 
time $t^{1}$, does not exist any longer at time $t^{2}$ (i.e., $s^{1}$ has no relationship with $t^{2}$ ). ${ }^{4}$ Conceived as proper cases of determined cognition, the reciprocal articulations of these terms may thus give rise to five fundamental alternatives.

\title{
First Configuration: A Temporal Being in a Potentially Empty Time (1.1)
}

According to this first hypothesis, every instance of the Being property (sattā) would always occur in time, which, however, does not always concern beings. Therefore, in this case, sattām kālatvam vyāpnoti, or 'Temporality pervades Being'.

\begin{abstract}
*[35] $s_{t}{ }^{\top} \boldsymbol{V}^{-1}\left\llcorner t_{t}\right.$
yā sattāvacchedakāvacchinna-viśeșyatā sā kālatva-nirūpitā; 'The relational abstract qualified-ness, conditioned by temporality, is limited by Being'; whose purport (tätparya, ${ }^{(\mathrm{t})}$ ) is: ${ }^{(\mathrm{t})}$ 'Being is always qualified by temporality; yet, there is a temporality independent from Being; that is, a sort of empty time'. Iff $\left|s_{t}\right| \subset \mid V^{-\mathbf{1}}\left\llcorner t_{t} \mid\right.$; i.e., 'The set Being $\left(\left|s_{t}\right|=\mathrm{S}\right)$ is a subset of What temporality $\left(\left|t_{t}\right|=\mathrm{T}\right)$ qualifies $(V)^{\prime}$; in standard notation (s.n.) $(\sim \forall x, \forall y$ $\sim \mathrm{T} x, \mathrm{~S} y)(\langle x, y\rangle \in V)$. Regarding the reasons for its falsity $(*)$, as well as of $*$ [36], *[37] and *[38], see infra $\$ 2$.
\end{abstract}

\section{Second Configuration: A Temporal Being in a Never-Empty Time (1.2)}

In this case, every being is necessarily in time. In parallel, temporality makes sense only if applied to beings. In other words, all beings (here, strictly speaking, existences) are always described in terms of temporality, and time is, likewise, always defined by events concerning those same existences. Indeed, what distinguishes instant $t^{1}$ from $t^{2}$ ? The fact that in $t^{1}$ the state of affairs $s^{1}$ is given,

\footnotetext{
Footnote 3 continued

the intimate substratum of the motion-viz., the sun' (svasamavāyisamyuktasamyoga). In this chain of indirect relation, the two extreme ends are the two relata-viz., motion on the one side and jar on the other. [Time is] this intermediate substance that bridges over the gulf between the sun and the jar". The fact that time (kāla) itself is one of the nine substances (dravya) of the Nyāya-Vaiśeșika system, and thus another proper occurrence of the property sattā, must not be overlooked; cf., NK, pp. 230-233; TrS (1930, p. 11); Potter (1977, pp. 91-93). Regarding the notion of existence and temporality, see also Halbfass (1992, pp. 205-228).

${ }^{4}$ Regarding $s^{1} \in\left|s_{t}\right|$, note that $s_{t}$ is the property of 'Being', in the meaning of the Greek einai or the Latin esse; $s^{1}$ accounts for a 'being', respectively to ón and ens, in Greek and Latin. Cf. also the analogous distinction in German between Sein (Being) and Seinden (being), Heidegger (1977, pp. 7-19). Regarding the definition of nityatva, cf. comm. Padakrtya in $\operatorname{TrS}$ (2007, p. 21): dvamsāpratiyogitvam prāgabhāvāpratiyogitvam vā nityatvam; 'permanence is [defined as] not being the counterpositive either of a destruction or of a pre-absence', that is, beginningless and endless. Nevertheless, I choose here to conduct a more articulate analysis via the different possible relations between sattā and kālatva. Regarding persistent cognition (dhārāvāhika-buddhi; Jha (2001, p. 210): "series of knowledge"; cf. also, TCM, p. 379) of a pot in a time slot according to the vedāntin account, and about the perceptibility of time, cf. Dharmarāja (1942, p. 4): nīrūpasyāpi kālasya indriyavedyatvābhyupagamena dhārāvāhikabuddher api pūrvapūrvajñānāvișaya-tattatkșana-viśeșa-viśiștavișayakatvena na tatrāvyāptih | kị̣ ca siddhānte dhārāvāhikabuddhisthale na jñ̄nabhedah; kim tu yāvat ghațasphuranam tāvad ghațākār$\bar{a}$ tahkaranavrttir ekaiva, na tu nānā, vrtteh svavirodhivrttyutpattiparyantam sthāyitvābhyupagamāt | tathā ca tatpratiphalitacaitanyarūpam ghațādijñānam api tatra tāvat kālikam ekam eveti nāvyāptiśankā 'pi|.
} 
while $s^{2}$ is given in $t^{2}$. If time and events are mutually dependent, then nothing permanent exists, since everything is in time; in parallel, there is time only in relation to beings. In this case, there would be a mutual pervasion (samavyāpti) between Being and Temporality: sattākālatvayoh samavyāptih. Thereby:

$*[36] t_{t} \backslash \mid \boldsymbol{V} s_{t}$ yathā yā kālatva-avacchedakāvacchinna-viśeșanatā sā sattā-nirūpitā, tathā yā sattā-avacchedakāvacchinna-viśeșyatā sā kālatva-nirūpitā; 'Just like the relational abstract qualifier-ness, conditioned by Being, is limited by temporality', so the relational abstract qualified-ness, conditioned by temporality, is limited by Being'; that is, ${ }^{(t)}$ 'Temporality qualifies some occurrences of Being' and 'Being is qualified by certain temporal determinations'; iff $\left(t_{t}^{\urcorner} \boldsymbol{V}\left\llcorner s_{t}\right) \wedge\left(s_{t}^{\urcorner} \boldsymbol{V}^{-\boldsymbol{I}}\left\llcorner t_{t}\right)\right.\right.$, i.e., $\left(\left|t_{t}\right| \subseteq \mid \boldsymbol{V}\left\llcorner s_{t} \mid\right) \wedge\left(\left|s_{t}\right| \subseteq \mid \boldsymbol{V}^{-1}\left\llcorner t_{t} \mid\right)\right.\right.$; therefore, $\left(\left|t_{t}\right|=\mid \boldsymbol{V}\left\llcorner s_{t} \mid\right) \wedge\right.$ $\left(\left|s_{t}\right|=\mid \boldsymbol{V}^{-1}\left\llcorner t_{t} \mid\right)\right.$, since in general if $\mathrm{A} \subseteq \mathrm{B}$ and $\mathrm{B} \subseteq \mathrm{A}$, then $\mathrm{A}=\mathrm{B}$. In other words, 'The set Temporality is coextensive with What qualifies Being' and 'The set Being is coextensive with What temporality qualifies'. In n.s. ( $\forall x, \forall y \mid \mathrm{T} x$, Sy) $(\langle x, y\rangle \in V)$.

\section{Third Configuration: A Potentially Atemporal Being in Relation with a Potentially Empty Time (1.3)}

In this case, combining and widening the first two configurations, there would be existences in time, beings out of time, as well as an empty time without events.
$*[37] t \rrbracket \mid \boldsymbol{V}\left\llcorner S_{t}\right.$
yathā yā tat-kāla-niștha-viśeșanatā sā sattā-nirūpitā, tathā yā tad-vastu-viśeșa- niștha-viśeșyatā sā kālatva-nirūpitā; 'Just like the relational abstract qualifier- ness, conditioned by Being, is limited at least by one temporal determination, so the relational abstract qualified-ness, conditioned by temporality, is limited at least by one occurrence of Being'; that is, ${ }^{(t)}$ 'Some temporal determinations qualify some beings'; iff $\left(t . \boldsymbol{V}\left\llcorner s_{t}\right) \wedge\left(s \cdot \boldsymbol{V}^{-\mathbf{1}}\left\llcorner t_{t}\right)\right.\right.$; i.e., $t \in \mid \boldsymbol{V}\left\llcorner s_{t}|\wedge s \in| \boldsymbol{V}^{-1}\left\llcorner t_{t} \mid ;\right.\right.$ ergo: $\mid$ $t_{t}|\cap| V_{\llcorner} s_{t}|\neq \varnothing \wedge| s_{t}|\cap| \boldsymbol{V}^{-1}\left\llcorner t_{t} \mid \neq \varnothing\right.$, 'The intersection between Temporality and What qualifies Being is not empty, because there is at least one temporal determination qualifying at least one instance of Being'; in parallel, 'The intersection between Being and What is qualified by temporality is not empty, since there is at least one specimen of Being qualified by temporality'; in s.n. $(\sim \forall x, \sim \forall y \mid \sim \mathrm{T} x, \sim \mathrm{S} y)(\langle x, y\rangle \in V)$. Regarding the term vastu, cf. supra fn. 2 .

\section{Fourth Configuration: An Atemporal Being and an Always Empty Time (1.4)}

The inevitable consequence of a third hypothesis, according to which the two properties Being and temporality never coincide, would be beings never marked by time and an absurd empty temporality which never concerns 'what is', but only 'what is not'. 
$*[38] t_{t} \rightleftharpoons \nexists^{-1} \mathrm{~L}\left(\boldsymbol{V} \mathrm{L} S_{t}\right)$

yā atyantābhāvīya-pratiyogitā kālatvāvacchinnā sā viśeșaṇatā-nirūpitāa, saiva viśeșanatā sattā-nirūpitā, tadviparyayena ca; 'Constant absentee-hood, limited by temporality, is conditioned by qualifier-ness, in turn conditioned by Being', and vice versa (\&vv)'; iff $\left|t_{t}\right| \cap\left|\boldsymbol{V}_{\llcorner} s_{t}\right|=\varnothing$, 'The intersection of Temporality and What qualifies Being is empty'; in s.n. $(\forall x, \forall y \mid \mathrm{T} x, \mathrm{~S} y)(\langle x, y\rangle \notin V)$.

\section{Fifth Configuration: A Potentially Atemporal Being in a Never Empty Time} (1.5)

In this case, beings qualified and beings not qualified by time are equally possible; conversely, kālatva is unavoidably a qualification of sattā.

[39] $t_{t}^{\urcorner} \boldsymbol{V} \mathbf{L} s_{t}$

yā kālatvāvacchedakāvacchinna-viśeșanatā sā sattā-nirūpitā; 'The relational abstract qualifier-ness, limited by temporality, is conditioned by Being', that is, (t) 'Every occurrence of temporality qualifies some, but not all, beings'; iff $\left|t_{t}\right| \subset \mid \boldsymbol{V}\left\llcorner s_{t} \mid\right.$, 'Temporality is a subset of What qualifies Being'; in s.n. $(\forall x, \sim \forall y \mid \mathrm{T} x, \sim \mathrm{S} y)(\langle x, y\rangle \in V)$.

\section{Defining Permanence (2)}

In order to decide which of these mutually exclusive configurations is adequate, the notion of permanence, as the starting point of VM's reasoning, will be questioned. If a generic being $s^{1}$ is said to be marked by temporality when it is limited or qualified by time $t^{1}\left(t^{l}\right\urcorner s^{1}$ or $\left.t^{l}\right\urcorner V \mathrm{~L} s^{1}$ ), then the expression of its permanence must consist, as a first step, in the negation of this assertion; that is, ' $s^{1}$ is not qualified by $t^{1}$. The target of this negation clearly cannot cover only $t^{l}$, but every possible temporal determination; that is, the whole temporal domain (i.e., $\left(t^{1}, t^{2}, \ldots, t^{n}\right) \in\left(\left|t_{t}\right|=\mathrm{T}\right)$, or $(\forall x \mid \mathrm{T} x))$. Consequently, the permanence to which $\mathrm{VM}$ is alluding has to be assumed as an indefectible being in the three times (trikāla; past, present, future). To properly express this quantification in NL, temporality $\left(t_{t}\right)$ must therefore appear in anuyogin position with respect to the relational abstract qualifier-ness $(\boldsymbol{V})$. The following provisional formula, limited to $s^{1}$ only, will be then obtained:

[40] $\left.s^{1} \cdot \nexists^{-1} \mathbf{L}\left(t_{t}\right\urcorner \boldsymbol{V}\right)$

yā atyantābhāvīya-pratiyogitā tattad-vastu-viśeșa-nișthā sā viśeșanatā-nirūpitā, saiva viśeșanatā kālatvāvacchinnā; ' Constant absentee-hood, conditioned by qualifier-ness, in turn limited by temporality, occurs in an instance of Being'; that is, (t)'A certain being is not qualified or determined by temporality'; iff $\left|t_{t}\right| \cap\left|\boldsymbol{V} s^{1}\right|=\varnothing$, since, $\left.s^{1} \notin \mid t_{t}\right\urcorner \boldsymbol{V} \mid$, 'The intersection between Temporality and What qualifies $s^{l}$ is empty', since, ' $s^{l}$ does not belong to the set What temporality qualifies'; in s.n. $(\forall x, \exists y \mid \mathrm{T} x, \mathrm{~S} y)(\langle x, y\rangle \notin V)$.

Provisional formula [40] is visibly compatible with *[38], for $(\forall x, \forall y \mid \mathrm{T} x, \mathrm{~S} y)$ $(\langle x, y\rangle \notin V)$. Does this compatibility imply that VM straightforwardly means *[38] 
here? Not quite. Although at this stage it is still not evident which truth conditions should be accepted, it is crystal clear that hypothesis *[38], expressing a radical separation between the domains Being and Temporality, is far more demanding than [40]. If it is still questionable whether there is a being out of time or faultlessly present in trikâla, it is beyond any doubt that innumerable existences are related to trikāla in a non-indefectible manner. Therefore, the intersection Being-Temporality cannot be said to be empty; ergo, *[38] is false. VM's issue would not even arise without admitting this entanglement, since it exactly faces the puzzling evidence of beings that, in time, appear and disappear, just because they were not, are, and will not be. This opens up two alternative options: it is possible to accept this appearance, while assuming an Instantaneist Hypothesis (I-Hy); or, along the lines of VM's analysis, to opt for the opposite account, claiming that no being may simply appear out the blue, but it always owes its existence to something else which somehow already exists. ${ }^{5}$ Once the latter alternative is accepted, either an endless causal chain is supposed-what I call C-Hy, Hypothesis of Continuum-or a perfectly independent and fully indefectible existence has to be admitted, acknowledging a causal infinite regress as a logical fallacy. I call this latter plexus of basic assumptions, the Hypothesis of Permanence (P-Hy). P-Hy describes permanency in its strongest sense as 'immutability' (kütastha-nityatā). C-Hy, claiming a 'permanency in transformation' or the 'permanency of what transforms' (parin̄āmi-nityatā), implies instead a form of continuity somehow metaphysically lighter and less committing. Nonetheless, every form of instantaneism (I-Hy), conceived as complete absence of continuity, is dismissed by virtue of C-Hy and $\mathrm{P}-\mathrm{Hy}$. This implies that only C-Hy and P-Hy will be considered in VM's analysis.

\section{Hypothesis of Continuum. Total Transformation (2.1)}

How then to decide between C-Hy and P-Hy? Let the first assumption be the hypothesis of continuity or permanence in transformation $(\mathrm{C}-\mathrm{Hy})$. This transformation might concern, in a first case, what transforms in its entirety (sarvātman);

\footnotetext{
5 Cf. Chānd. Up. 6.2.1-2 (1998, p. 247): 1. «In the beginning, son, this world was simply what is existent [...]. Now, on this point some do say: 'In the beginning this world was simply what is nonexistent [...]. And from what is nonexistent was born what is existent'». 2. «But, son, how can that possibly be?». Regarding, instead, a possible origin from non-Being in the Upanișads, cf. Halbfass (1992, p. 41 fn. 18), quoting: Chānd. Up. 3.19.1; Br. Up. 1.2.1; Tai. Up. 2.7. For a brief survey of Ratnakīti's list of attempts to define Being, in the broader contest of the philosophical issue regarding Being (cf. fn. 4) in India and not only, see Id. (1992, pp. 24-25). In compliance with the said doxography, in these pages, use will be made of the following definitions of Being, depending on the context: 1) "inherence of (the universal) reality" (sattāsamavāya); 2) "being subject to origination, decay and stability" (utpādavyayadhrauvyayogitva), 3) "being the domain (and condition) of valid cognition (pramānavișayatva)". See also BSBh 1.1.2 (2018, p. 47): vastuvrttam api, janmanā labdhasattakasya dharminah sthitipralayasambhavāt | asyeti pratyakșādisamnidhāpitasya dharmiṇa idamā nirdeśạ | șașțī janmādidharmasambandhārthā | yata iti kärananirdeśah |; "The fact as it is, is that it is only when a thing possessing attributes has attained the condition of existence, that preservation and dissolution of the same are possible. The word 'asya' (in the sütra) indicates the thing possessing attributes, which is established by direct means of knowledge etc. as -this is it. The genitive case (of asya) is for showing the relation with the origin, etc. The word 'yatah' indicates by the ablative case the cause (of the origin)", as trans. by Apte in BSBh (1960, p. 10); cf. also: Śāstrī-Raja, in VM-B (1933, p. 121). The dismissal of I-Hy is far from easy; regarding its defence by, e.g., Ratnakīrti, see McDermott (1969, pp. 41-43, 71-72).
} 
that is, completely and without residue. The consequence, VM argues, will inevitably be a contradiction (vyāhati) with "what [this transforming whole is supposed] to be" (tattva). Indeed, if $s^{1}$ completely transforms into $s^{2}$, the following conditions are necessarily required:

A. $\left(s^{1}, s^{2}\right) \in\left|s_{t}\right|$; 'beings $s^{1}$ and $s^{2}$ belong to the set Occurrences of Being (sattāa)', since both are something and not nothing, such as a hare's horn (śaśaśringa);

B. $\left.\left(t^{l}\right\urcorner \boldsymbol{V}_{\llcorner} s^{l}\right) \wedge\left(t^{2} \neg \nexists^{-1}\left\llcorner\left(\boldsymbol{V}_{\llcorner} s^{l}\right)\right)\right.$; because, $s^{l} \in \mid \boldsymbol{V}^{-1}\left\llcorner t^{l} \mid\right.$, but $s^{l} \notin \mid \boldsymbol{V}^{-1}\left\llcorner t^{2} \mid\right.$ (i.e., $s^{l}$ is qualified by $t^{1}$, but not by $t^{2}$; in $t^{2}, s^{l}$ is no more, having fully transformed into $\left.s^{2}\right)$;

C. $\left(t^{2}\right\urcorner \boldsymbol{V}\left\llcorner s^{2}\right) \wedge\left(t^{1} \neg \nexists^{-1}\left\llcorner\left(V_{\llcorner} s^{2}\right)\right)\right.$; because, $s^{2} \in \mid \boldsymbol{V}^{-1}\left\llcorner t^{2} \mid\right.$, but $s^{2} \notin \mid \boldsymbol{V}^{-1}\left\llcorner t^{1} \mid\right.$ (i.e., $s^{2}$ is qualified by $t^{2}$, but not by $t^{1}$; in $t^{1}, s^{2}$ is not yet, $s^{1}$ not having transformed into $\left.s^{2}\right)$

D. $s^{1} \neq s^{2}$; because $s^{1}$ has fully transformed, without residue, into $s^{2}$.

Condition $\mathrm{D}$ is nonetheless in glaring contradiction with both condition $\mathrm{A}$ and, on a more general level, TvN. For a transformation without residue to come about, each and every property must transform, none excluded. Now, $s^{l}$ is said, at a minimum, to be (for $\left.s^{l} \in \mid s_{t}\right)$ ). Clearly, the transformation would not be total if this property too would not fully undergo this transformation. It follows that $* s^{2}$ must not be a being' (for $*^{2} \notin\left|s_{t}\right|$ ), which is utterly false, not only because ' $s^{2}$ is a being' (for TvN), but also on the transformative account itself, which otherwise would not accomplish the purpose for which it has been invoked, that is, explaining how a being could convert into another one, e.g., how milk may turn into curd. Undermining the continuity linkage, a transformation of the sarvātman type violates the very basis of C-Hy and reveals itself as a form of unintentional instantaneism. Sarvātmaparināma not only allows, but imposes the awkward passage from milk to hare's horn: tattvavyāhati, in VM's words (cf. fn. 1). In order to avoid this contradiction, at least the property $s a t t \bar{a}$ has thus to be maintained throughout the process (condition A: $\left.\left(s^{1}, s^{2}\right) \in\left|s_{t}\right|\right)$. Therefore, the impossible idea of a transformation in toto, without any residue, must be abandoned. Furthermore, also the exclusion of the hypothesis expressed $s u b *$ [35] and *[36] inevitably follows. Since this first variant of C-Hy is inadmissible, a sort of continuity has to be admitted; thus, it is false that every specimen of sattā is always and in every aspect determined by kālatva. It is now clearer what the provisional formula [40] has already expressed: $\left|t_{t}\right| \mathrm{\cap}\left|\boldsymbol{V}_{\mathrm{L}}{ }^{1}\right|=\varnothing$, or $(\forall x, \exists y \mid \mathrm{T} x$, Sy) $(\langle x, y\rangle \notin V)$, which is clearly incompatible with $*[35]$, for $(\sim \forall x, \forall y \mid \sim \mathrm{T} x, \mathrm{~S} y)$ $(\langle x, y\rangle \in V)$, and $*[36]$, for $(\forall x, \forall y \mid \mathrm{T} x, \mathrm{~S} y)(\langle x, y\rangle \in V)$, because there is at least an instance of sattā which is not limited by time.

For the time being, formulae *[37] and [39] are the last two hypothesis still standing. Nevertheless, $*[37] t \rrbracket \mid \boldsymbol{V}\left\llcorner s_{t}\right.$ simultaneously suggests that there is at least one instance of sattā free from time determinations, as well as a temporality without reference to Being. It follows that:

*[37 a $] t \Uparrow \boldsymbol{V} \mathbf{L} \overline{s_{t}}$

yathā yā tat-kāla-niștha-viśeșaṇatā sā asattā-nirūpitā, tathā yā tad-avastuviśeșa-niștha-viśeșyatā sā kālatva-nirūpitā; 'Just as the relational abstract qualifier-ness, conditioned by non-Being $\left(\overline{s_{t}}\right)$, is limited at least by one 
temporal determination, so the relational abstract qualified-ness, conditioned by temporality, is limited at least by one occurrence of non-Being'; that is, (t) 'Some temporal determinations qualify some non-beings'; iff $\left|t_{t}\right| \cap\left|\boldsymbol{V} \mathrm{L} \overline{s_{t}}\right| \neq \varnothing \wedge\left|\overline{s_{t}}\right| \cap \mid \boldsymbol{V}^{-1}\left\llcorner t_{t} \mid \neq \varnothing\right.$ ('The intersection between the extension of the property temporality and the set Qualifiers of non-Being is not empty, since there is at least one temporal determination qualifying non-Being; in parallel, 'The intersection between the extension of the property non-Being and the set What temporality qualifies is not empty, since there is at least one specimen of non-Being qualified by temporality); in s.n. $(\sim \forall x, \sim \forall y \mid \sim \mathrm{T} x, \sim \bar{S} y)(\langle x, y\rangle$ $\in V$ ). Regarding the term avastu, cf. supra fn. 2 .

Assertion $*\left[37_{\mathrm{a}}\right]$ must necessarily result from *[37]; if not-that is, if temporality would not qualify any specimen of non-Being (for $\left|t_{t}\right| \cap\left|\boldsymbol{V}_{\llcorner} \overline{s_{t}}\right|=\varnothing$ )_formula $*$ [37] would then be reducible to [39], for $\left|t_{t}\right| \subseteq \mid \boldsymbol{V}\left\llcorner s_{t} \mid\right.$ —that is, there are specimen of Being not qualified by temporality, but any temporal coordinates of what is not. Consequently, asserting *[37] would necessarily imply, according to its corollary* $\left[37_{\mathrm{a}}\right]$, that:

A. $\left.t^{1}\right\urcorner s^{1}$, for $s^{1} \in\left|s_{t}\right|$; i.e., ' $s^{1}$ is limited by time $t^{1}$;

B. $\left.t^{2}\right\urcorner \overline{s^{2}}$, for $\overline{s^{2}} \in\left|\overline{s_{t}}\right|$; that is 'A non-being (such as a hare's horn), occurrence of What is not, is determined by a temporal coordinate').

Yet, condition B is a flat nonsense, since at time $t^{2}$ there is no such hare's horn that could possibly be qualified by it. Ergo, *[37 $]$ is false because it is false that $\left|t_{t}\right| \cap\left|\boldsymbol{V}_{\llcorner} \overline{s_{t}}\right| \neq \varnothing$, since only $\left|t_{t}\right| \cap\left|\boldsymbol{V} \overline{s_{t}}\right|=\varnothing$ can be true. It follows that $*$ [37] cannot be true. Consequently, kālatvam sattā vyāpnoti (cf. supra), as expressed in [39], has proven to be the only option not yet contradicted.

\section{Hypothesis of Continuum. Partial Transformation with Distinction (2.2.1)}

If transformation cannot be total (cf. $\S 2.1$ ), VM suggests, it might be only partial. This means that, once transformation in toto has been ruled out, according to the hypothesis of partial transformation (ekadeśa-parināma), a single aspect, at the very least, must persist throughout the process. Now, in the case of partial transformation, VM wonders, is the part in evolution distinct or not distinct from the part that, on the contrary, does not evolve? If there is distinction (bhinnatva) between the part in transformation and the non-evolving part of that subject in partial transformation, which in toto does not evolve, can it be argued that it is that very same non-evolving subject to evolve and not another, since what transforms has been explicitly defined as distinct from what does not? ${ }^{6}$

\footnotetext{
${ }^{6}$ Cf. Larson (1988, pp. 164-165): “The term satkārya literally means 'existent effect', but in classical Sāmkhya it implies much more than this literal meaning. The term satkārya appears in Kārikā IX, and five reasons [hetu] are given to explain the phenomenon. (1) Because of the non-productivity of non-being; (2) because of the need for an (appropriate) material cause; (3) because of the impossibility of all things coming from all things; (4) because something can only produce what it is capable of producing; (5) because of the nature of the cause (or, because the effect is non-different from the cause)"; asadakaraña upādānagrahaṇāt sarvasambhavābhāvāt | śaktasya śakyakaraṇāt kāraṇabhāvāc ca satkāryam || SK 9 (1934, p. 42) ||. Cf. also SK 3, 15, 16 (1934, pp. 14, 71, 76). See also Larson (1988, p. 50): "the sixty
} 
The hypothesis under examination imposes that $s^{1}$ possesses at least two aspects or parts, say $s^{l(A)}$ and $s^{l(B)}$. Of this two parts, $s^{l(A)}$ does not evolve, whereas $s^{1(B)}$ is the evolving aspect. The unchanging part $s^{1(A)}$ will remain, by definition, at time $t^{2}$ identical to what it was at time $t^{1}$. In NL:

[41] $\left.\left(t^{2}\right\urcorner s^{1(A)}\right)$. I ᄂ $\left.\left(t^{1}\right\urcorner s^{1}\right)$

yā tatkāla-avacchinna-tadvastv-ekadeśa-niștha-tādātmyatā pūrva-kāla-avacchinna-tad-vastu-nirūpitā; 'Identity occurs in a single part of a particular being, limited by this particular temporal coordinate and is conditioned by the very same particular being limited by a temporal coordinate preceding the former'; iff $t^{1} \neq t^{2}$ and $\left.\left(t^{2}\right\urcorner s^{1(A)}\right) \in\left|\boldsymbol{I}\left\llcorner\left(t^{1}\right\urcorner s^{1}\right)\right|$; i.e., $\left\langle s^{1}, s^{1(A)}\right\rangle \in I\left(s^{1}\right.$ is identical to $\left.s^{1(A)}\right)$.

The two aspects of $s^{1}, s^{l(A)}$ and $s^{1(B)}$ have been defined to be distinct (bhinna) qua opposite-since, respectively, non-evolving and evolving. How to conceive this distinction? In the light of what precedes (cf. P2.§9), bheda might be usefully reinterpreted, salva veritate, as a generic negation of the relation of coreferentiality (sāmānāähikaranya, $N$ ). The distinction between $s^{1(A)}$ and $s^{1(B)}$ can therefore be expressed in NL as:

[42] $\left.\left(t^{2}\right\urcorner s^{1(A)}\right) . \nexists^{-1}\left\llcorner\left(N_{\mathbf{L}}\left(t^{2}\right\urcorner s^{1(B)}\right)\right)$

yā tat-kāla-avacchinna-tad-vastv-ekadeśa-niștha-atyantābhāvīya-pratiyogitā

sā sāmānādhikaranyatā-nirūpitā, saiva sāmānādhikaranyatā tat-kālaavacchinnaitad-vastv-ekadeśa-nirūpitā; 'Constant absentee-hood, conditioned by coreferentiality in turn conditioned by this single part $\left(s^{1(B)}\right)$ of a particular being $\left(s^{1}\right)$ limited by that temporal coordinate $\left(t^{2}\right)$, occurs in that single part $\left(s^{1}\right.$ (A) of the [very same] particular being $\left(s^{l}\right)$ limited by the [very same] temporal coordinate $\left(t^{2}\right)$ '; that is, ${ }^{(\mathrm{t})}$ 'Qua parts of being $s^{1}, s^{1(A)}$ and $s^{1(B)}$ are, at time $t^{2}$, distinct'; iff $\left.\left.\left(t^{2}\right\urcorner s^{1(A)}\right) \notin \mid N_{\mathrm{L}}\left(t^{2}\right\urcorner s^{1(B)}\right) \mid$ (i.e., 'At time $t^{2}$, part $s^{1(A)}$ of being $s^{1}$ does not belong to the set What is coreferential to part $s^{1(B)}$ of being $s^{1}$ at time $t^{2}$ ).

Nevertheless, considering both [41] and [42], it necessarily follows:

[43] $\left.\left(t^{2}\right\urcorner s^{1}\right) \cdot \nexists^{-1}\left\llcorner\left(N\left\llcorner\left(t^{2}\right\urcorner s^{1(B)}\right)\right)\right.$

yā tat-kāla-avacchinna-tad-vastu-niștha-atyantābhāvīya-pratiyogitā sā sāmānādhikaranyatā-nirūpitā, saiva sāmānādhikaranyatā tat-kāla-avacchinnaitadvastv-ekadeśa-nirūpitā; 'Constant absentee-hood, conditioned by coreferentiality, in turn conditioned by this single part $\left(s^{l(B)}\right)$ of a particular being $\left(s^{l}\right)$ limited by that temporal coordinate $\left(t^{2}\right)$, occurs in that [very same] particular being $\left(s^{l}\right)$ limited by the [very same] temporal coordinate $\left(t^{2}\right)^{\prime}$; that is, (t) Being $s^{l}$ and its own part $s^{1(B)}$ are, at time $t^{2}$, distinct, qua noncoreferential'.

Footnote 6 continued

topics (șasthitantra) [cf. SK 72] which include the ten basic principles dealing with the nature of puruṣa and prakrti $[\ldots]$ ". Regarding the aforesaid sixties and their first ten, as "radical categories" (maulikārthāh smrtā daśa) (Larson 1988, pp. 135-138), cf. their enumeration by VM himself (VM-T 1896, pp. 113114). 
The reason is that, if $\left\langle s^{1}, s^{1(A)}\right\rangle \in I$ (i.e., $s^{1}$ and $s^{1(A)}$ are identical; cf. [41]) and $\left.\left.\left(t^{2}\right\urcorner s^{l(A)}\right) \notin \mid N_{\mathrm{L}}\left(t^{2}\right\urcorner s^{1(B)}\right) \mid$ (i.e., $s^{l(A)}$ and $s^{1(B)}$ are distinct at time $t^{2}$; cf. [42]), then $\left.\left.\left(t^{2}\right\urcorner\left(\left\langle s^{l}, s^{\dot{I}(A)}\right\rangle \in I\right)\right) \notin \mid N_{\mathrm{L}}\left(t^{2}\right\urcorner s^{l(B)}\right) \mid$ (i.e., $s^{l}$ and its part $s^{1(A)}$ are both distinct, qua identical, from $s^{l(B)}$ at time $\left.t^{2}\right)$. Therefore, the transforming part $s^{1(B)}$ turns out to be different, by absence of coreferentiality, from the being which is supposed to transform (i.e., $s^{l}$ ). If the transforming being is a distinct being, then the subject of transformation is not transforming, since another thing is been transformed. VM labels this fallacy as 'over-application' (atiprasainga) ${ }^{7}$ of the concept of transformation, according to which it is first and foremost the subject of transformation to be supposed to transform and not other. It is this clay which may eventually transform into a pot, surely not that horse. By virtue of formulas [41]-[43] the hypothesis of the partial transformation of a distinct aspect also has to be discarded.

Hypothesis of Continuum. Partial Transformation Without Distinction (2.2.2)

Once transformation in toto and partial transformation with distinction have both been excluded, it might be the case of a partial transformation without distinction (abhinna). Yet, if the evolving and non-evolving parts are non-distinct, how to distinguish one from another? The issue is straightforward and the VM's discussion the most concise. Either there is a distinction between evolving and non-evolving parts, or there is not. If there is a distinction, then there is nothing but partial transformation with distinction (cf. \$2.2.1); if there is no distinction, this new solution simply falls back into the previous case of the transformation in toto (cf. $\S 2.1)$.

\section{Hypothesis of Continuum. Conclusive Refutation (2.3)}

VM opens his analysis by laying down the radical alternative between 'permanency as immutability' (küțastha-nityatā; P-Hy) and 'permanency in transformation' (parināmi-nityatā; C-Hy). The third possibility, impermanency tout court (I-Hy), is simply expunged: what is not permanent either is not and never will be, or it owes its existence to what is permanent. In other words, the contrast between permanency and impermanency is only apparent and it has been reduced to the most fundamental one between different forms of permanency. Nevertheless, since permanency in transformation inevitably generates contradictions, all that remains is permanency as immutability of that which, indefectible, never changes.

\footnotetext{
7 NK, p. 7: atiprasaingah-[1] ativyāptiḥ । [2] prakrtād anyatra prasañganam. TrS Dīpikā, 4 (1951, p. 12): avyāptih [...] | ativyāptih [...] | [...] asambhavah | etaddūṣaṇatrayarahito dharmo lakșaṇam | sa evāsādhāraṇadharma ity ucyate | lakșatāvacchedakasamaniyatatvam asādhāraṇatvam |; "A lakșaṇa is a specific feature or asādhāranadharma. The term asādhāranadharma means that which is free from the three faults of a definition-viz.: over-applicability (ativyāpti), partial inapplicability (avyāpti) and total inapplicability (asambhava)". Jha (2001, pp. 3, 339): "[ativyāpti] The fault called over-application, i.e. existing in the definiendum (lakșa) and also in other than the definiendum". Cf. also NK, pp. 695-698.
} 


\section{Difference and Non-difference. The Accepted Assumptions (3)}

Since the possibilities of transformation in whole $(\$ 2.1)$ and in part, with $(\S 2.2 .1)$ or without (\$2.2.2) distinction, have been definitely excluded, the subject in transformation paradoxically appears to be at once distinct and non-distinct from itself, according to the perspective from which it is observed (cf. infra). Simultaneously, the curd is no more and yet still milk, as well as a bracelet is and is not just gold. In P2 has been argued how, in the case of a golden bracelet, the gold of which the bracelet is made cannot in any manner whatsoever be said equivalent $(E)$, equal $(Q)$ or identical $(I)$ to the bracelet itself. Nonetheless, it is no less true that this specimen of gold and this bracelet, coreferential (samānädhikarana) to the former, are nothing but the very same object. This is the reason why they are said to be, stricto sensu, non-different (abhinna). Reshaping the definition of 'unit' as advanced by Gadādhara (1929, p. 167; eka as kaivalya), non-difference (abheda) has been defined in P2.\$5 as 'not being the counterpositive of a difference occurring in another coreferential property'. Regarding the case of a golden bracelet, formula P2.[27] $h .2\llcorner m$, by virtue of that counterpositive structure (cf. P2. [34]), will therefore appear as:

$$
\text { [44] }\left(\left(\left(h \cdot \boldsymbol { N } \llcorner b ) \rightleftharpoons \nexists ^ { - 1 } \llcorner ( \boldsymbol { I } ^ { 1 } \llcorner b ) ) \urcorner \mathbb { N } \left\llcorner\left(1_{t}\right)\right.\right.\right.\right.
$$

yad atyantābhāvīyapratiyogitā-avacchedakāvacchinna-paryāptitvam tad ekatvanirūpitam; tatra yaiva atyantābhāvīyapratiyogitā hātaka-niṣtha-kațaka-nirūpitasāmānādhikaranyatā-avacchedakāvacchinnā sā anyonyābhāvīyapratiyogitā-nirūpitā, eșaiva anyonyābhāvīyapratiyogitā kațaka-nirūpitā; tadviparyayena ca; 'The relational abstract constant absentee-hood $\left(\nexists^{-\mathbf{1}}\right)$, limited by coreferenceness $(\boldsymbol{N})$, in turn conditioned by a bracelet $(b)$ and occurring in a specimen of gold $(h)$, is conditioned by mutual absentee-hood conditioned by the same bracelet, \&vv; for a cardinality equal to one'; iff $\mid h . N_{\bullet}\left\llcorner b|\notin| \boldsymbol{F}^{\mathbf{1}}\llcorner b \mid\right.$ (i.e., 'A specimen of gold coreferential to a bracelet does not belong to the set What is different from that bracelet'); that is, $\left(h \in \mid \boldsymbol{N}\llcorner b \mid) \wedge\left(\mid \boldsymbol{N}\left\llcorner b|\nsubseteq| \boldsymbol{F}^{\mathbf{1}}\llcorner b \mid)\right.\right.\right.$ (i.e., 'A specimen of gold belongs to the set What is coreferential to a bracelet' and 'The set What is coreferential to a bracelet is not a subset of What is different from that bracelet'), for card $\{h, b\}=1$ ('The cardinality of the set containing a specimen of gold and a bracelet is equal to one'), and clearly, as a general premise, $h \in\left(\left|h_{t}\right|=\mathrm{H}\right), b \in\left(\left|b_{t}\right|=\mathrm{B}\right), \mathrm{H} \cap \mathrm{B} \neq \varnothing$ (respectively: 'A specimen of gold belongs to the set What is gold, extension of the property gold-ness', 'A bracelet belongs to the set Bracelets, extension of the property bracelet-hood', 'The intersection of the sets What is gold and Bracelets is not empty', since at least one golden bracelet exists). Cf. infra $§ 8$, for a further discussion.

In the words of VM:

Whether that [subject, which is supposed to be in transformation, and which can yet transform neither in whole nor in part] is [said to be, consequently] distinct and non-distinct (a/bhinna), then, this will be non-distinct qua cause, and distinct qua effect; just as in the case of bracelets (kataka) or other 
artifacts $(\bar{a} d i)$, which are non-distinct qua gold, but distinct qua bracelets or other artifacts. Nor [is it correct to say that], by contradiction (virodha) between difference and non-difference, it is not [possible] a relation of inherence (samavāya) in the very same locus (ekatra) [of these two aspectsthat is, cause and effect, or gold and bracelet]. ${ }^{8}$

Indeed, inherence (samavāya)—reason for the contextual perception (pratyayahetu) of coreferential properties - is defined as the relation which occurs between an inherent (samaveta) and an inhered (samavāyin) qua indivisible (ayutasiddha), as in the examples of the quality and the qualified (a blue pot), the whole and its parts (a pot and its halves), the general kind and the individual (potness and pot), etc. ${ }^{9} \mathrm{VM}$ points here to the fact that the peculiar opposition of two distinct properties does not exclude their coreferentiality in singularity (ekatra) via inherence. Following VM, if the relation standing between gold and bracelet cannot unquestionably be reduced to reflexive identity stricto sensu ( $I$; cf. P2 $\S 3$ ), for the time being it stands to reason

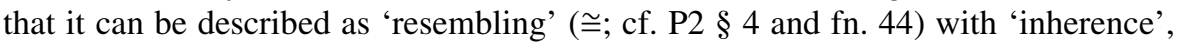
as well as somehow consequently admitting a distinctive, structural, although dangerously paradoxical, 'compatibility with difference' (bhedasahiṣnutva; cf. P2 fn. 58). And yet, one could ask, how is this bizarre juxtaposition conceivable? And where does it originate from?

\section{Difference and Sources of Knowledge (4)}

For our part, where [should] the right conception (sampratyaya), regarding the opposition (viruddha) [between different properties referring to the very same thing, be retraced]? This [opposition] occurs by reason of the [inevitable] 'obversion' (viparyaya) [operated] by the sources of knowledge (pramāna). Indeed, just as something is [correctly] understood by means of the [relative] source of knowledge, so is its [proper] condition (bhāva), [and not another].

\footnotetext{
8 VM-B (2018, p. 72): bhinnābhinnam tad iti cet, tathā hi tad eva kārañātmanābhinnam, bhinnam ca kāryātmanā, kațakādaya ivābhinnā hāțakātmanā bhinnāśs ca kațakādyātmanā | na ca bhedābhedayor virodhān naikatra samavāya iti yuktam |.

9 NK, pp. 959-962: ihedam iti yatah kāryakāraṇayoh sa samavāyah | tadarthaś ca kāryakāraṇayor avayavāvayavinor yatah sambandhāt ihedam iti pratyayah sa samavāyah | ayutasiddhānām ādhāryādhārabhūtānām yạ̣ saṃbandhaḥ iha pratyayahetuḥ sa samavāyaḥ iti (cf. Praśastapāda 1994, p. 86) | [...] sa ca yathā avayavāvayavinoh gunaguninoh kriyākriyāvatoḥ jātivyaktyoh viśeșanityadravyayoś ca sambandhah (cf. TrS 2007, p. 169) | yathā ghațakapālayoh sambandhah samavāyah | evam anyatrāpi ūhyam | taduktam ghațādīnām kapālādau dravyeșu guṇakarmaṇoḥ | teșu jāteś ca saṃbandhah samavāyaḥ prakīrtitah || (cf. NSM 1988, p. 130) iti|. Cf. Matilal (1968, p. 39): "It has been conceived as a permanent relation in the sense that it connects the adjunct to the subjunct in such a way that the adjunct can never occur or exist as separated from the subjunct. It may be noted in this connection that the subjunct of an inherence relation can, however, continue to exist even when the adjunct ceases to exist, i.e., ceases to occur in the subjunct by inherence". See also, NK, p. 963: samavāyitvam-samavāyānuyogitvam | yathā kapāle ghațasamavāyitvam guṇakriyayoś ca samavāyitvam dravye |; NK, p. 963: samavetam—kasmimnścit dravyagunakarmātmake vastuni samavāyasambandhena vidhyamānam | yathā mrdā samavāyenotpādyam ghațātmakam kāryam kapāle samavetam bhavati $\mid$. Thus, $(\langle$ colour, pot $\rangle \in S)=\left(\langle\right.$ pot, colour $\left.\rangle \in S^{-1}\right)$; for samavāya ('inherence', $S$ ), samavetatva ('inherent-hood', $\boldsymbol{S}$ ), samavāyitva ('inhered-hood', $\boldsymbol{S}^{-1}$ ).
} 
[Let us consider, for instance, the cognition], 'This earring is gold': in [that distinctive] cognitive evidence (pratyaya) [which is said at once] syntactical homogeneity and coreferentiality (sāmānādhikaranya, $N$ ), both difference and non-difference clearly appear. ${ }^{10}$

About what opposition (viruddha) is VM talking? Clearly, about the opposition between the properties gold-ness and bracelet-hood, which are certainly not one and the same. Nonetheless, in case of a golden bracelet, there is but one single being, yet considered from different perspectives. The opposition, that is, distinction, between the aforesaid properties is not a cause for contradiction about their coreferentiality. Therefore, to what does VM ascribe this irreducible opposition which, nonetheless, does not apparently generate any contradiction with respect to coreferentiality? To the epistemic process itself, answers VM. Is he possibly alluding to a knowing subject who mistakes mother-of-pearl for silver or a rope for a snake? Not at all. The subject correctly recognises here both the bracelet and the gold of which the former is made. Indeed, this bracelet can be worn, as well as the gold melted and reshaped. On the contrary, the mother-of-pearl mistaken for silver cannot ever be melted, just like a rope cannot bite or produce any effect different from those proper to a rope, such as tying or being mistaken for a snake. Gold and bracelet are here properly known and their presence or condition of existence (bhāva) is correctly defined as the result of the knowing processes (pramāna) of which they are objects (vișaya). ${ }^{11}$

\footnotetext{
${ }^{10}$ VM-B (2018, p. 72): viruddham iti nah kva sampratyayah? yat pramānaviparyayena vartate $\mid$ yat tu yathā pramānenāvagamyate tasya tathā bhāva eva| 'kuṇdalam idam suvarnam' iti sāmānādhikaranyapratyaye vyaktạ bhedābhedau cakāstah $\mid$. VM here quotes verbatim the Maṇana Miśra's following passage (1937, p. 63): viruddham iti nah kva sampratyayah? yat pramānaviparyayena vartate | yat tu yathā pramānnenāvagamyate tasya tathā bhāve viruddhatvābhidhāne kam batāyam āśritya hetum viruddhatvāviruddhatve vyavasthāpayet? pramāṇam caikasya sāmānyaviśesātmakatām avagamayati, vyāvṛttyanuvṛttibhyām prakhyārūpabhedāt aikādhikaranyāvagamāe ca (sāmānāāhikaranyāvagamāc ca; Maṇạana Miśra-G) | tad idam asāmpratam, yato nedṛśạ̄ vipratiṣiddhārthajñānānām prāmānyam eva yujyate saṃśayajñānavat | anyathā saṃśayavișayo 'pi dvyātmā syāt, dvyābhāsatvāt tasya sāmānādhikaranyāe ca tadavabhāsayoh |. Cf. also VM-TS (2006, pp. 92-98). The peculiar lexical choice for viparyaya as 'inversion' and then 'obversion' will be discussed in detail in P4.

${ }^{11}$ Cf. BSBh 1.1.2 (2018, p. 47). Regarding the notion of worldly (vyāvahārika) truth or veridicality (pramā) and pragmatic success (arthakriyāsāmarthya), also in the vivaraṇa framework, cf. Prakāsātman (1892, p. 31). According to NN, practical behaviour cannot constitute a proper criterion of definition of pramā, but only a logically subsequent verification tool: TCM (2009, p. 220): na api samartha-pravrttijanakānubhavatvam | upekșā-pramāyām avyāpteh | tad-yogyatāyāh pramā-nirūpyatvāt |; "Nor 'awareness that leads to successful activity'. This would not include those veridical awareness which result in an attitude of indifference (that are not acted upon). Furthermore (this characterization exhibits the fault of 'self-dependence' in that) the potentiality here (for successful activity) presupposes veridical awareness"; cf. also Mohanty in TCM (2006, p. 35). It should also be noted that, despite the fact that "Nyāya philosophers [undoubtedly] embrace the correspondence theory of truth or veridicality, [...] [that is], 'as the object, so the cognition' [yathārthatva]" (Phillips 2012, p. 6), Gañgeśa's account is far more polished: TCM (2009, p. 236): yatra yad asti tatra tasya anubhavah pramā | tadvati tat-prakārakānubhavo vā | yatra yan na asti tatra tasya jñānam tad-a-bhāvavati tat-prakāraka-jñānam vā apramā |; "Veridical awareness is 'awareness of something there where it is'. Or, 'awareness with $\phi[$ tat $]$ as predication content about an object that is $\phi^{\prime}$. [...] Another translation: veridical awareness is 'an awareness that $\phi x$ only if $\phi x$ ', in other words, an awareness that an object is $\phi$ only if it is indeed $\phi$ ". Cf. also Phillips in TCM (2009, p. 237). Regarding the notion of bhāvavacana, cf.: MW (p. 754, 3): "signifying a state or action, denoting the abstract notion of a verb". B (IV, p. 262): "einen Zustand, eine Thätigkeit, den abstracten Verbalbegriff bezeichnend". Renou (1957, pp. 243-244): "Etat: définissant chez P. [Pāṇ.] V 1119 la
} 
According to TvN, "what possesses the property of being that, is that" (tadvattvam tad eva). Consequently, to be the bracelet that it is, a bracelet (b) has to be cognized as possessing that particular property which makes it a bracelet and not something else; that is, bracelet-hood $\left(b_{t}\right)$. Otherwise, no bracelet would be cognized and the issue raised by VM would have never risen. Idem for gold. The determined cognition by means of which bracelet and gold are correctly cognized inevitably and simultaneously opposes them. It is not a matter of perceptual illusion or epistemic dysfunction, since the point is here far more serious. Placing itself to the opposing end of the knowing process and not being possible to grasp it otherwise, in which manner an object (prameya) is known via the respective source of knowledge (pramāna) so it is (bhāva). In other terms, the prameya's ontological status appears to inevitably depend on the means of knowledge by which the former is known. Therefore, what is correctly known always relies on what I call a 'refined definition' (parișkāra-lakșaṇa) supplied by a well-conducted knowing process; that is, a definition which thus turns out to be obstinately recurring regardless of how many times the analysis might be repeated. Here, then, is the opposition to which VM alludes. A consolidated epistemological triptych secures the ordered succession of uddeśa (the preliminary enunciation or denomination of what has to be known, the prameya); lakșana (the definition of the prameya by means of a peculiar feature, capable of distinguishing it, vyāvrtti, from all the rest-tattvavyavacchedaka or tattvaparicchedaka); and the parīkșā (the examination or assessment, by means of the relative knowledge source or pramana, of the appropriateness of the advanced definition to the object under scrutiny). ${ }^{12}$ In compliance with this triptych, laksana cannot but precede the use of knowledge sources, since this use is committed to the endorsement of the former. On the contrary, I here intend to refer to this sort of 'refined definition' (parișkāra-lakșaṇa), polished, validated, and therefore, having passed the test of parīssāa, somehow conclusive. In this sense, pariṣkāra-lakșaṇa necessarily follows the intervention of pramannas. At the end of the process of knowing, the prameya is revealed to be just what the pramanas have reported it to be. In the case of the golden bracelet correctly known, the sources of knowledge themselves unify and oppose two distinct properties in the very same locus. Therefore: etat kim? ('What's this?'); idam kațakam ('This is a bracelet'); idam hạtakam ('This is gold'); idam hătaka-kațakam ('This is a golden bracelet').

Footnote 11 continued

valeur des suffixes -tva- tā- [...]. Ce qui exprime un état". Cf. Pān. 5.1 .119 (1999, p. 504): tasya bhāvas tva-tālau, "The taddhita affixes tva and taL occur to denote bhāva, 'characteristic state', after a syntactically related nominal stem which ends in śașthi, 'genitive' ".

12 Cf. Vatsyāyana's commentary ad NS 1.1.3 (2009, p. 266): trividhā cāsya śātrasya pravrttih - uddeśo lakșaṇam parīkșā ceti | tatra nāmadheyena padārthamātrasya abhidhānam uddeśah | tatra uddiștasya tattvavyavacchedako dharmo lakșaṇam | lakșitasya yathālakșaṇam upapadyate na veti pramānair avadharaṇam parīkṣa |; "La mise en œuvre du traité a un triple objectif: désigner, caractériser, examiner. L'uddeśa 'désignation' ou 'énonciation' consiste à se référer à la chose simplement par son nom. Le lakṣaṇa 'définition' ou 'caractérisation', c'est le fait de dire la propriété qui distingue l'essence de la chose désignée. La parīkșā 'investigation' ou 'examen' c'est le fait de déterminer avec les moyens-deconnaissances-droite si, oui ou non, l'entité définie est conforme à sa définition”. Cf. also NK, pp. 155, 488, 695; Jha 2001, pp. 110-111, 262, 339. See also supra fn. 7. 


\section{Reflexiveness, Mutual Absence and Locus Sharing (5)}

In the light of the above, the terms of the question are at once plainly clear and utterly paradoxical. VM does emphasise their puzzling effect by juxtaposing both the extremes of the spectrum in a single comprehensive passage. The formal tools acquired in $\mathrm{P} 1 \& \mathrm{P} 2$ have fulfilled all the necessary conditions for the detailed analysis of the following passage, while definitely demonstrating the unviability of the evoked, more nuanced, partial solutions.

In case of an absolute (atyantika) non-difference, the undesired outcome (prasanga) of a double occurrence (dviravabhāsa) [is inevitably determined] (cf. §5.1); [whether] an absolute distinction [is instead supposed, then there will be] no coreferentiality (sāmānādhikaranya) at all, as between a cow and a horse (cf. §5.2). [Moreover], no coreferentiality [can be given in the context of] a relation of substratum-superstratum (ādhāra-ādheya-bhāva; cf. §5.3.1), or of 'residing in one locus' (ekāśrayatva; cf. §5.3.2). [Nobody would say that] 'A jujube (Ziziphus Jujuba) is the bowl', [only on the grounds that the jujube is in that bowl]; as well as, regarding [the two friends] Caitra and Maitra, [who are sitting] on the same bench, that 'Caitra is Maitra'. ${ }^{13}$

\section{Absolute Reflexive Non-difference (5.1)}

VM starts his analysis facing the case of a possible absolute non-difference (átyantika-abheda) ruling the relation between gold and bracelet. Yet, if the relation of absolute non-difference is interpreted as the complete impossibility of distinguishing between the two properties, then this entails their reduction to one and the consequent collapse of abheda into a tautological reflexive relation; that is, in the VM's words, the 'undesired event of a double appearance' (dviravabhāsaprasanga; cf. P1.§2). Therefore, the cognition 'suvarnam idam kundalam' ('This earring is gold') will turn into 'kuṇdalam idam kuṇdalam' or 'suvarnam idam suvarnam' ('This earring is an earring' or 'This gold is gold'). The issue is straightforward: once any possibility of distinguishing between the relata has been negated by hypothesis, ST (Substitutivity Test), LL (Leibniz's Law), and PII (Principle of Identity of Indiscernibles, although controversial) will find a proper application, and the relation will collapse into identity tout court. The impossible reduction of non-difference to identity-discussed in depth in P2.\$4-finds here further confirmation. ${ }^{14}$ Hereafter, in order to avoid any external reference to the NN

\footnotetext{
13 VM-B (2018, p. 72): tathā hi ātyantike 'bhede 'nyatarasya dviravabhāsaprasangah | bhede cātyantike na sāmānādhikaranyam gavāśvavat | ādhārādheyabhāve ekāśrayatve vā na sāmānādhikaranyam, na hi bhavati kuṇdam badaram iti | nāpy ekāsanasthayoś caitramaitrayoś caitro maitra iti I. A little further along, VM reaffirms the same concept; VM-B (2018, p. 73): katham tarhi hema kundalam iti sāmānādhikaranyam iti cet, na hy ādhārādheyabhāve samānāśrayatve vā sāmānādhikaranyam ity uktam I.

14 Accordingly, it is strictly speaking false that: *'A bracelet is identical to a specimen of gold'. It

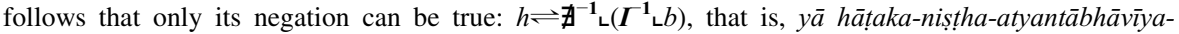
pratiyogitā sā tādātmyatā-nirūpitā, saiva tādātmyatā kațaka-nirūpitāa, tadviparyayena ca ( ${ }^{(t)}$ ' A specimen of gold is the limitor of the constant absence of identity with respect to a bracelet', or ${ }^{(t)}$ 'Gold and bracelet are not identical'); iff: a) $\left(h^{\prime} \neq f^{\prime} b^{\prime}\right) \wedge(h \neq b)$ (i.e., 'The terms 'gold' and 'bracelet' are different and so are
} 
framework, I propose to express a logical function roughly analogous to the one performed by LL through what I call tādātmīya-kārana-naya (TKN) or the Identity Reduction Rule: tādātmye sati satatam samaniyatatva-ātyantikābhedav anubhātah ('Given identity, equality and perfect non-difference [in every respect] necessarily follow'). Let taddharmavattva $\left(t d_{t}\right)$ and etaddharmavattva $\left(e d_{t}\right)$ be the generic properties, being that and being this, for $t \in\left|t d_{t}\right|$ and $e \in l e d_{t} \mid$ (i.e., ' $t$, is a specimen of being that, and belongs to the set What is that'; the same applies for $e d_{t}$ ). Thereby, it could be stated that:

$$
\begin{aligned}
{[\mathrm{TKN}] } & e \cdot N\llcorner t \\
& \left(e \cdot e d _ { t } \rightleftharpoons \boldsymbol { I } \llcorner t \cdot t d _ { t } ) { } ^ { \top } \mathbb { N } \left\llcorner\left(1_{t}\right)\right.\right. \\
& \therefore \quad\left(( ' e ' \urcorner \boldsymbol { S } \llcorner e d _ { t } ) \rightleftharpoons \boldsymbol { Q } \llcorner ( { } ^ { \prime } t ' \urcorner \dot { S } \llcorner t d _ { t } ) ) \wedge \left(e d _ { t } \rightleftharpoons \nexists ^ { - 1 } \left\llcorner\left(\boldsymbol{I}^{-1}\left\llcorner t d_{t}\right)\right)\right.\right.\right.
\end{aligned}
$$

tad etad (bhavati) ity uktvā, tan-niștha-taddharmavattvaitan-nișthaitaddharmavattvayor tādātmyaikatve sati, taddharmavattvaitaddharmavattve samaniyata ity taddharmavattvaitaddharmavattve 'bhinna iti cānuvartate ${ }^{15}$; whose purport is: ${ }^{(\mathrm{t})}$ 'If that $(t)$ is $(N)$ this $(e)$, in the meaning of a relation of identity $(I)$, for a cardinality equal to one [since that and this are the very same object], then perfect equality $(Q)$ and non-difference $(z=\nexists(t))$, between the property being that $\left(t d_{t}\right)$ and being this $\left(e d_{t}\right)$ occurring in that $(t)$ and this $(e)$, necessarily follow'; iff:

A. $\operatorname{card}(N)=1$; i.e., relation $N$ involves one single object;

B. $e \in\left|e d_{t}\right| \wedge t \in\left|t d_{t}\right|$, for $\mathrm{TvN}$; viz., this and that are proper occurrences of the generic properties being this and being that, lest they be not what they are;

C. $\langle e, t\rangle \in I$; that is, 'This and that are identical';

D. ' $e$ ' $=$ ' $t$ ', for $\left(\left|e d_{t}\right|=\mathrm{ED}\right)=\left(\left|t d_{t}\right|=\mathrm{TD}\right)$; i.e., the generic properties being that and being this are coextensive or, in other words, the same property (as in the case of: sāsnādimatī gauh, 'A cow or the [animal] possessing dewlap, etc.'; cf. P2.§2); therefore, the terms by means of which these coextensive properties are expressed are reciprocally interchangeable (e.g., sāsnādimatī gauh or gaur gauh);

\footnotetext{
Footnote 14 continued

their denotations'); b) $h \in\left(\left|h_{t}\right|=\mathrm{H}\right) \wedge b \in\left(\left|b_{t}\right|=\mathrm{B}\right) \wedge \mathrm{H} \neq \mathrm{B}$ (respectively: 'A specimen of gold belongs to the set Gold'; 'A bracelet belongs to the set Bracelets'; 'Gold and Bracelets are not the same set'); c) $\langle h$, $b\rangle \notin I$ (i.e., ' $h$ and $b$ are not identical', consequently they cannot pass the ST).

15 It should be noted here that, in general, $I$ is $Q$ arthatah, while $Q$ is $I$ śabdatah (respectively, "from an extensional' and 'from a linguistic point of view'; cf. P2.\$2-3), and $I \subseteq z$. In the above formulae, $\boldsymbol{S}$ stands for śakyatā ('primary meaningfulness'; cf. P2.\$2). Moreover, for the sake of simplicity, the TKN formulation is visibly read in short form. Its complete Sanskrit reading would instead reads as follows: yadi yā etanniștha-sāmānādhikaranyatā sā tannirūpitā, yadi ca yat tādātmyatā-avacchedakāvacchinnaparyāptitvam tad ekatva-nirūpitam, saivaitannișthaitaddharmavattva-avacchedakāvacchinna-tādātmyatā tanniștha-taddharmavattva-nirūpitā, tadviparyayeṇa ca, tarhi yad etat-pada-avacchinnaitaddharmavattva-nirūpita-śakyatā-avacchedakāvacchinna-samaniyatatvam tat tat-pada-avacchinna-śakyatānirūpitam, eșaiva śakyatā taddharmavattva-nirūpitā, tadviparyayeṇa ca, punaś ca yaitaddharmavattvaavacchedakāvacchinna-atyantābhāvīya-pratiyogit $\bar{a}$ sā anyonyābhāvīyapratiyogitā-nirūpitā, saiva anyonyābhāvīyapratiyogitā taddharmavattva-nirūpitā, tadviparyayeña ca.
} 
E. dviravabhāsa-prasaingābhavah; that is, 'The undesired event of a double appearance does not occur'; in standard logic terms, all the expressions pass the Substitutivity Test, since the said double occurrence of a term does not affect the expression's truth values and its overall meaning. ${ }^{16}$

If it is true that the bracelet is gold or non-different from gold (cf. [44]), TKN definitely shows, on the contrary, how it is utterly false to say that the bracelet is stricto sensu identical to gold, since bracelet-hood and gold-ness are beyond any doubt not coextensive. The proper expression of the relation standing between these properties is, instead, a formula conveying the non-empty intersection between two sets (cf. infra, §5.2, [45 $]$ and fn. 17).

\section{Mutual Exclusion and Coreference Rule (DSN) (5.2)}

As a second step, VM excludes by contradiction the hypothesis of difference (bheda) qua 'mutual exclusion' (anyonyābhā va; $f$ ) between properties reciprocally distinct (bhinna). If there were mutual exclusion, there would not be any coreferentiality between gold-ness and bracelet-hood, just as in the case of cowhood and horse-hood. Yet, this is clearly not the case. Formula [44] - true for $h \in \mathrm{I}$ $\Lambda \mathbf{N} b b \mid$; i.e., 'A specimen of gold belongs to the set What is coreferential to a bracelet' - asserts that gold-ness and bracelet-hood are coreferential, at least in one case: the golden bracelet under exam. In general terms and via reductio ad absurdum, let us prove by means of what I call Dharma-Sāmānādhikaranya-Naya (DSN; Properties Coreference Rule) that if two properties are coreferential at least in one case, they cannot be said to be mutually absent.

In the assertion 'tad etad bhavati' (i.e., 'That is this' or ' $t$ is $e$ '), a single case of coreference $(N)$ is premised:

[45] $t$. N $\mathrm{L}$ ᄂ

yā tan-niștha-sāmānāahikaranyatā saitad-nirūpitā; that is, ${ }^{(\mathrm{t})}$ ' $t$ and $e$ are coreferential'; iff:

A. $e \in\left(\left|e d_{t}\right|=\mathrm{ED}\right)$; for TvN, ' $e$ belongs to set ED, extension of the property $e d_{t}$ (lest $e$ not be $e$ )'. Ergo: $e=e \cdot e d_{t}$; that is, etanniștham etaddharmavattvam ('Property $e$-hood occurs in $e^{\prime}$ ).

B. Regarding $t$, ditto;

C. $t \in \mid N$ เe $\mid$, i.e., 'That $(t)$ belongs to set What is coreferential to this (e)'.

Let us now analyse, in compliance with the truth conditions of [45] which only imposes at least one case of coreferentiality, the least onerous possible relation standing between the properties $t d_{t}$ and $e d_{t}$ through the application of the operator 'yathā-tathā' ('just like-so', لl; cf. Anrò 2022: §4.3), capable of expressing a nonempty intersection between two sets:

\footnotetext{
${ }^{16}$ Alternatively, by modus ponens and with reference to P2.§4-5: $((I \rightarrow Q) \subseteq(z \subseteq N)) \wedge I \vdash(Q \subseteq(z \subseteq M))$; that is, whether 'If Identity $(I)$ then Equality $(Q)$, since $I$ is $Q$ arthatah, while $Q$ is $I$ śabdatah (P2.\$2-3. [22]-[26]), and $I$ and $Q$ are particular cases of Non-difference (z), which is a particular case of coreference $(N)$ ' and 'There is Identity', then 'There are Equality and Non-difference'. In general: $a \in \mathrm{A} \wedge \mathrm{A} \subseteq \mathrm{B} \vdash$ $a \in \mathrm{B}$.
} 
$\left[45_{\mathrm{a}}\right] t \int \uparrow \boldsymbol{N} \mathrm{L} e d_{t}$ yathā yā sāmānādhikaranyatā tannișthā saitaddharmavattva-nirūpitā, tathā yā viparīta-sāmānādhikaranyataitanniștha sa saddharmavattva-nirūpitā; that is, ${ }^{(t)}$ ' Just like at least one occurrence of the property $t d_{t}$ is coreferential to $e d_{t}$, so at least one occurrence of the property $t d_{t}$ is coreferential to $e d_{t}^{\prime}$; iff

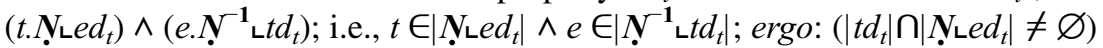
$\wedge\left(\left|e d_{t}\right| \cap \mid \boldsymbol{N}^{\mathbf{1}}\left\llcorner t d_{t} \mid \neq \varnothing\right)\right.$; i.e., 'The intersection of the sets $\left|t d_{t}\right|$ and What is coreferential to the property ed $d_{t}$ is not empty' or, roughly speaking, 'There is at least one $t$ which is $e$ '; moreover, 'The intersection of the sets $\left|e d_{t}\right|$ and What is inversely coreferential to the property $t d_{t}$ is not empty'; that is, 'There is at least one $e$ which is $t$ '; or TnE $\neq \varnothing$ (for $\left|t d_{t}\right|=\mathrm{T}$ and $\left.\left|e d_{t}\right|=\mathrm{E}\right)$; in s.n. $(\sim \forall x$, $\sim \forall y \mid \sim \mathrm{TD} x, \sim \mathrm{ED} y)(\langle x, y\rangle \in N)$.

For instance, there are undoubtedly golden bracelets, yet not every bracelet is golden and gold is not always a bracelet. ${ }^{17}$ Despite the above, the mutual absence (anyonyābhāva, $I$; here again expressed as: $\nexists^{-\mathbf{1}}\left\llcorner\Gamma^{\mathbf{1}}\right.$, cf. P2.§3) between the properties $t d_{t}$ and $e d_{t}$ be forcibly imposed:

$*\left[45_{\mathrm{b}}\right] t d_{t} \rightleftharpoons \nexists^{-\mathbf{1}} \mathrm{L}\left(\boldsymbol{\Gamma}^{\mathbf{1}}\right.$ Led $\left._{t}\right)$

yā taddharmavattva-avacchedakāvacchinna-atyantābhāvīya-pratiyogit $\bar{a} \quad$ sā tādātmyatā-nirūpitā, saiva tādātmyataitaddharmavattva-nirūpitā, tadviparyayena ca; 'Constant absentee-hood, limited by the property being that, is conditioned by mutual absentee-hood, in turn conditioned by the property being this, \&vv'; that is, ${ }^{(t)}$ 'Properties $t d_{t}$ and $e d_{t}$ are completely distinct or mutually exclusive, since where there is the former, the latter is always absent, \&vv'; iff $\left|t d_{t}\right| \cap \mid \Gamma^{\mathbf{1}}$ Le $d_{t} \mid=\varnothing$, in other words, TDNED $=\varnothing$ (i.e., the intersection between the sets Extension of property $t d_{t}$ and Extension of property $e d_{t}$ is empty); in s.n. $(\forall x, \forall y \mid \mathrm{TD} x, \mathrm{ED} y)(\langle x, y\rangle \notin N)$ (for $I \subseteq N$, cf. $\mathrm{P} 2 . \S 5)$.

According to the NL syntax rules (cf. Anrò 2022, §5), a complex 'consideration' (parāmarśa; Bhattacharyya, 1987, pp. 178-182) can now be built by substitution, combining $*\left[45_{\mathrm{b}}\right]$ with $\left[45_{\mathrm{a}}\right]$ :

$*\left[45_{\mathrm{c}}\right]\left(t \sqrt{\|} \boldsymbol{N}\left\llcorner e d_{t}\right) \rightleftharpoons \nexists^{-\mathbf{1}}\left\llcorner\left(\boldsymbol{I}^{\mathbf{1}}\left\llcorner\left(t \| \uparrow \boldsymbol{N}\left\llcorner e d_{t}\right)\right)\right.\right.\right.\right.$

whose purport is ${ }^{(t)} *$ 'Property $t d_{t}$, which in its occurrence $t$ is coreferential to $e d_{t}$, is completely distinct or mutually absent with respect to property $e d_{t}$, which in its occurrence $e$ is coreferential to $t d_{t}^{\prime}$; iff TDกED $\neq \varnothing$ (for $\left[45_{\mathrm{a}}\right]$ ) and TDNED $=\varnothing$ (for $*\left[46_{b}\right]$ ); that is, *'The intersection between the sets Extension of property $t d_{t}$ and Extension of property $e d_{t}$ is both not empty and empty'.

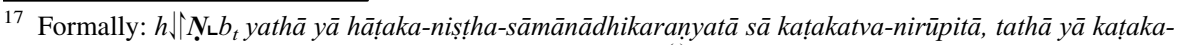

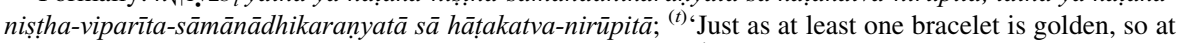
least one specimen of gold is a bracelet'; iff: $\left(h . N_{\mathrm{V}} b_{t}\right) \wedge\left(b . \boldsymbol{N}^{-\mathbf{1}}\left\llcorner h_{t}\right) \leftrightarrow h \in\left(\left|h_{t}\right|=\mathrm{H}\right) \wedge b \in\left(\left|b_{t}\right|=\mathrm{B}\right) \wedge h \in \mid\right.$ $\Lambda\left\llcorner b_{t}|\wedge b \in| \boldsymbol{N}^{-1}\left\llcorner h_{t} \mid\right.\right.$ (i.e., 'A specimen of gold belongs to the set What is coreferential to certain bracelets', as well as 'A bracelet belongs to the set What is coreferential to certain specimen of gold') $\therefore\left(\left|h_{t}\right| \cap\left|N_{\mathbf{L}} b_{t}\right|\right.$ $\neq \varnothing \wedge\left|b_{t}\right| \cap \mid N^{-1}\left\llcorner h_{t} \mid \neq \varnothing\right)=((\mathrm{H} \cap \mathrm{B}) \neq \varnothing)$ (it follows that the intersection between the extensions of the properties gold-ness and bracelet-hood is not empty); in s.n., $(\sim \forall x, \sim \forall y \mid \sim \mathrm{H} x, \sim \mathrm{B} y)(\langle x, y\rangle \in N)$.
} 
Formula $*\left[45_{\mathrm{c}}\right]$ is a downright contradiction in terms, violating the reciprocal semantical compatibility (yogyatā) of its own components; therefore, $*\left[45_{\mathrm{c}}\right]$ is always false $(\perp) .{ }^{18}$ In general, it can now be stated:

$\operatorname{DSN}\left(t . N\left\llcorner\llcorner) \wedge\left(t d_{t} \rightleftharpoons \nexists^{-1}\left\llcorner\left(\boldsymbol{\Gamma}^{\mathbf{1}}\left\llcorner e d_{t}\right)\right) \rightarrow \perp\right.\right.\right.\right.$

$\therefore t d_{t} \rightleftharpoons \nexists^{-1}\left\llcorner\left(\nexists_{t}^{-1}\left\llcorner\left(\Gamma^{-1}\left\llcorner e d_{t}\right)\right)\right.\right.\right.$

tan-niștha-sāmānādhikaranyatāyām etan-nirūpitāyām satyām yadi yā taddharmavattva-avacchedakāvacchinna-atyantābhāvīya-pratiyogitā sā tādātmyatānirūpitā, saiva tādātmyataitaddharmavattva-nirūpitā tadviparyayeṇa ca, tarhi virodhah sambhavati; tatah pratiyogitā-a-bhāvah; whose purport is: ${ }^{(t)}$ 'Given the coreference between this and that, the mutual absence between the relative properties is no more possible and its assertion is always false $(\perp)$. Therefore $(\therefore)$, only the negation of this negation can be true'. ${ }^{19}$

In conclusion, by virtue of DSN, whenever the coreferentiality between two occurrences of non-coextensive properties is premised, then it is always impossible to interpret the mutual distinction between these properties qua constant mutual absence (atyanta-anyonyābhāva).

\section{The Fruit is Not the Bowl and the Bench of Caitra and Maitra (5.3.1)}

Having excluded both the interpretations of coreferentiality $(N)$ as identity $(I$; $\mathrm{cf}$. $\S 5.1$ ) and mutual absence ( $;$; cf. §5.2), VM now clears the ground from possible misinterpretations in terms of $\bar{a}$ dhāra-ädheya-bhāva $(L)$. I call it 'Hypothesis of substratum-superstratum' (L-Hy). Let us first consider the classical relational paradigm of substratum-superstratum $(L)$ - 'A pot $(p)$ on the ground $(g)$ ', as clearly distinct objects connected by contact:

[46] $(g$. $\boldsymbol{L}\llcorner p)\urcorner \mathbb{N}\left\llcorner\left(2_{t}\right)\right.$

yad āśrayatā-avacchedakāvacchinna-paryāptitvam tad dvitva-nirūpitam; yaiva bhūtala-niștha-āśrayatā sā ghața-nirūpitā; 'The relational abstract locus-hood, limited by the ground, is conditioned by a pot, for $\operatorname{card}(L)=2$ '; iff $g \in \mid \boldsymbol{L}\llcorner p \mid \wedge$ $\mathrm{G} \cap \mathrm{P} \neq \varnothing \wedge \operatorname{card}(L)=2$ (respectively, 'A certain ground belongs to the set Loci of a pot'; 'The intersection between the sets Grounds and Pots is empty', since grounds which are also pots do not exist; for the same reason, their cardinality is equal to two; that is, that ground plus one pot); in s.n. ( $\exists x, \exists y$ $\mathrm{G} x, \mathrm{P} y)(\langle x, y\rangle \in L)$.

\footnotetext{
18 Cf. NK, p. 675; Jha (2001, pp. 331-332): "compatibility, one of the factors facilitating understanding of sentence meaning"; Phillips (2012: 90-91, 103): "semantic fitness".

19 Regarding reductio ad absurdum, see Whitehead-Russell (1910, p. 104): “2.01. $: p \supset \sim p . \supset$. $\sim p$ This proposition states that, if $p$ implies its own falsehood, then $p$ is false"; Lee (1973, p. 385, n. 1): "Briefly, the technique is that where $\sim q$ is the conclusion to be derived, one assumes $\sim q$, derives $r \sim r$ from $\sim q$ and the premises, and then derives $q$ from $r \cdot r$ [..]". Cf. also Phillips (2012, p. 167): "prasanga: dialectical difficulty, [...] such as contradiction or infinite regress". On double negation in Nyāya, see Guha (1979, pp. 207-208) and Shaw (1987). Note the introduction of the second level relational abstract ' $\nexists_{t}^{-\mathbf{1}}$ '; for the relative discussion, see fn. 23 .
} 
Yet, premise [44] $\left(\left(\left(h . N\llcorner b) \rightleftharpoons \nexists^{-1}\left\llcorner\left(\boldsymbol{F}^{-1}\llcorner b)\right) \neg N\left\llcorner\left(I_{t}\right)\right.\right.\right.\right.\right.$ must be reaffirmed, for $h \in \mid \boldsymbol{N}\llcorner b \mid, \mathrm{B} \cap \mathrm{H}$ $\neq \varnothing$, and $\operatorname{card}\{h, b\}=1$ (i.e., 'A specimen of gold belongs to the set What is coreferential to a bracelet'; 'The intersection of the sets What is gold and Bracelets is not empty'; 'The cardinality of the set containing a specimen of gold and a bracelet is equal to one'). It clearly follows that $N \neq L$; that is, 'The relation of coreferentiality is completely different from the relation of substratum-superstratum, since they do not share any common pairs' (cf. P2.\$4 and fn. 44). Therefore, $L$ is never a valid interpretation of $N$, being a special case of contact (samyogasambandha; $M)$ : for $(N \neq(L \subseteq M)) \subseteq V$. If 'There is a pot on the ground' (bhütale ghatah; $L^{(M)}$ or $L$ qua $\left.M\right)$, that does not imply that *'The pot is the ground' (*bhütalam ghatah; $N$ ), just as, if there is a jujube in a bowl, it does not follow that the jujube is the bowl. ${ }^{20}$ Also appealing to a possible 'relation of sharing by contact the same basis' (ekāśraya-samyoga-sambandha ${ }_{1} L^{(M)}$ ) for a cardinality greater than one $\left(\operatorname{card}\left({ }_{1} L^{(M)}\right) \geq 2\right)$ will be of no avail in this regard. In the words of VM, if Caitra and Maitra sit on the same bench (for $\operatorname{card}\left({ }_{1} L^{(M)}\right)=3$ ), this does not either turn Caitra into Maitra, or even less the two friends into their bench. ${ }^{21}$

\section{Mysterious Indeterminate Variables (5.3.2)}

A second variant of this last hypothesis is subtler. Indeed, it could be objected that distinct properties might possibly share a single locus (eka-āśraya) not via contact (samyoga) and for an imposed cardinality equal to one (card $\left.\left({ }_{1} L\right)=1\right)$, solving in this manner the contradiction between their utter distinction and their joint manifestation. I call it, 'Hypothesis of sharing a sole locus' (1L-Hy). For instance, properties gold-ness and bracelet-hood, properly conceived in their distinctions and prerogatives, might occur in a further basis, locus, receptacle, or sub-ject (etymologically). This formulation, not unintentionally, displays many similarities with that which is commonly expressed in standard notation: $(\exists x \mid \mathrm{H} x \wedge \mathrm{B} x)$; that is,

\footnotetext{
${ }^{20}$ Cf. P1.\$2 and fn. 14. Regarding the relation of contact (samyoga), cf. NK, p. 924; TrS (1951, p. 94): samyuktavyavahārahetuh samyogah | sarvadravyavyavrttih $\|$; "Contact is the special cause of expressions such as 'these are in contact with each other'. It is found in all the substances"; Guha (1979, pp. 43-44): "Samyoga or contact is an occurrence-exacting relation. It is a quality ( $g u n a$ ) and it is supposed to exist in more than one substance (dravya) through the relation of inherence (samavāya)"; italics are mine.

21 Therefore, the 'relation of sharing by contact the same basis' (ekāśraya-samyoga-sambandha; ${ }_{1} L^{(M)}$, for $\operatorname{card}\left({ }_{1} L\right) \geq 2$ ), is indistinguishable from the relation of 'substratum-superstratum' (ādhāra-ādheyabhāva; $L$ ); that is, ${ }_{1} L^{(M)} \subset L$. Moreover, relation ${ }_{1} L^{(M)}$, qua contact and for $\operatorname{card}\left({ }_{1} L^{(M)}\right)=3$ (e.g., Caitra, Maitra, and the bench), is also a clear case of avyāpya-vrtti, or "non pervaded occurrence" (Jha 2001, p. 68). Cf. NK, p. 99: avyāpyavrittitvam svātyantābhāva-samānādhikaranam; Ingalls (1951, pp. 73-74): "A relation is said to be of incomplete occurrence (avyapya-vrtti) if it is a relation such that $x$ occurs in only part of $y$. Contact, and the absence of an entity by contact, are the only relations of this sort that will concern us"; Guha (1979, p. 43): "[Contact or samyoga] is generally known as a relation of incomplete occurrence (avyāpya-vrtti), because when a contact takes place between two substances (dravya), it occurs only in a part of them, if of course, the two substances have parts". For instance, a monkey can only sit on a portion of a branch, and not on the whole tree: eka-śäkhā-avacchedena kapi-vrkșa-samyogaḥ; regarding definition and example cf., among the many, NK, p. 84: [ga]—avacchedakatva; and Ingalls (1951, p. 74): "The naiyāyikas recognize that 'limitor' here has a different sense [...]. They gloss it by 'simā-paricchedaka' - delimitor of the (physical) boundary. In this sense, the locus (e.g., branch) of a locus (e.g., tree) of an entity (e.g., contact with monkey) may limit that entity".
} 
there is an unspecified variable $x$, acting in the capacity of sub-ject or ontological basis, able to collect a series of distinct properties, such as being gold and being a bracelet. Despite the Nāgārjuna's ante litteram confutations, the general strategy is thus, first, to summon up a "bare particular" in order to subsequently attribute to it a collection of properties in coordination. ${ }^{22}$ On that premise, VM asks, how to interpret this attribution of properties to a generic common basis?

Let us suppose the intervention of a common indeterminate basis ' $a$ ' (anirnittasādhārana-äśraya) being the middle term between two distinct relata (here, being gold and being bracelet) via the 'relation of sharing the same basis' (ekāsrayasambandha; $\left.{ }_{1} L\right)$ :

$[47 \mathrm{a}] a \cdot{ }_{1} \boldsymbol{L} \mathrm{L} h_{t}$

yā ekāśrayatā anirṇīta-sādhārana-āśraya-nișthā sā hātakatva-nirūpitā;

${ }^{(t)}$ 'Gold-ness occurs on/in a sole, common, indeterminate basis or sub-ject';

iff $\left.a \in\right|_{1} L\left\llcorner h_{t} \mid\right.$ (i.e., 'The indeterminate, single, basis $a$ belongs to the set What on/in which, qua sole basis, at least one instance of gold-ness occurs).

In parallel, being $a$, the common indeterminate sole basis of a bracelet too, according to $1 \mathrm{~L}-\mathrm{Hy}$ it must similarly be affirmed that:

[47 $] a \cdot{ }_{1} \boldsymbol{L}$ ᄂ $b_{t}$

yā ekāśrayatā anirṇīta-sādhārana-āśraya-nișthā sā kațakatva-nirūpitā;

${ }^{(t)}$ 'Bracelet-hood occurs on/in a sole, common, indeterminate basis or $s u b$ ject'; iff $\left.a \in\right|_{\boldsymbol{I}} \boldsymbol{L}\left\llcorner b_{t} \mid\right.$ (i.e., 'The one and only indeterminate basis $a$ belongs to the set What on/in which, qua sole basis, at least one instance of bracelet-hood occurs).

Composing, by substitution, $\left[47_{\mathrm{a}}\right]$ and $\left[47_{\mathrm{b}}\right]$ in a complex judgment (parāmarśa), the result would then be:

$\left[47_{\mathrm{c}}\right]\left(a \cdot{ }_{1} \boldsymbol{L}_{t}\left\llcorner h_{t}\right){ }_{1} \boldsymbol{L}\left\llcorner b_{t}\right.\right.$

yā ekāśrayatātva-avacchedakāvacchinna-ekāśrayatā sā kațakatva-nirūpitāa; tad evaikāśrayatātvam anirṇîta-sādhārana-āśraya-niș̣tham hạtakatva-nirūpitam ca; 'The relational abstract being a common locus $\left({ }_{1} \boldsymbol{L}\right)$, conditioned by bracelet-hood $\left(b_{t}\right)$, is limited by the [same] relational abstract being a common locus, conditioned by gold-ness $\left(h_{t}\right)$, which in turn occurs on/in a sole, common, indeterminate basis or sub-ject (a)'; that is, ${ }^{(t)}$ 'Bracelet-hood occurs on/in an indeterminate single basis, which is the very same basis on/in which also gold-ness occurs'; iff $\left(\left.a \in\right|_{1} \boldsymbol{L}_{t}\left\llcorner h_{t} \mid\right) \subseteq\left({ }_{1} \boldsymbol{L}\left\llcorner b_{t} \mid\right)\right.\right.$ (i.e., 'The basis $a$ belongs to the set What on/in which, qua sole basis, at least one instance of gold-ness occurs; the latter is in turn a subset of What on/in which, qua sole basis, at least one instance of bracelet-hood occurs'). ${ }^{23}$

\footnotetext{
22 Nāgārjuna (1999, p. 119): 2.3. gamyamānasya gamanam katham nāmopapatsyate| gamyamānam hy agamanam yadā naivopapadyate; "How is it possible the movement of the moving? Since the nonmovement of the moving is not possible" (trans. is mine). I follow here Phillips (1997, p. 19).

23 The introduction of the relational abstract ekāśrayatatva $\left({ }_{1} \boldsymbol{L}_{t}\right)$-a second level abstract, derived from ekāśrayatā $\left({ }_{1} \boldsymbol{L}\right)$-is to be noted. Regarding the naiyāyika technique of double abstraction, cf. Ingalls (1951, p. 45): "A double abstraction [...], e.g. father-ness-ness". The double abstract-preventing the
} 
Now, which truth values should be attributed to $\left[47_{\mathrm{c}}\right]$ ? As the sole alternative (cf. $\S .5 .3 .1)$, the cardinality of the relation of 'sharing the same basis' ${ }_{1} L$ ) has to be hypothesized as strictly equal to one $\left(\operatorname{card}\left({ }_{1} L\right)=1\right)$ :

$\left[47_{\mathrm{d}}\right]\left(\left(a \cdot{ }_{1} \boldsymbol{L}_{t}\llcorner h)\right\urcorner{ }_{1} \boldsymbol{L}\right.$ ᄂ $\left.\left.b\right)\right\urcorner \mathbb{N}\left\llcorner\left(1_{t}\right)\right.$

yat paryāptitvam ekāśrayatā-avacchedakāvacchinnam tad ekatva-nirūpitam; saivaikāśrayatātva-avacchedakāvacchinnaikāśrayatā hātaka-nirūpitā; tad eva avacchedakaikāśrayatātvam anirṇīta-sādhārana-āśraya-niștham hātaka-nirūpitam ca; iff:

A. $\left(\operatorname{card}\left({ }_{1} L\right)=1\right) \wedge\left(a \in \mid{ }_{l} \boldsymbol{L}_{t}\llcorner h \mid) \rightarrow\left({ }_{1} \boldsymbol{L}_{t}\llcorner h \mid=\{a\}) \therefore(a=h)\right.\right.$; i.e., if the cardinality of relation of 'sharing the same basis' $\left.{ }_{1} L\right)$ is equal to one and $(\wedge)$ the one and only indeterminate basis a belongs to the set What on/in which, qua sole basis, a specimen of gold occurs, then $(\rightarrow)$ the set What on/in which, qua sole basis, a specimen of gold occurs must possess the basis a qua its sole element; therefore $(\therefore)$, the basis $a$ and the specimen of gold $h$ are nothing but the same element.

B. $\left(\operatorname{card}\left({ }_{1} L\right)=1\right) \wedge\left(a \in \mid{ }_{1} \boldsymbol{L}\llcorner b \mid) \rightarrow\left(\mid{ }_{1} \boldsymbol{L}\llcorner b \mid=\{a\}) \therefore(a=b)\right.\right.$; i.e., if the cardinality of relation of 'sharing the same basis' $\left({ }_{1} L\right)$ is equal to one and $(\wedge)$ the one and only indeterminate basis a belongs to the set What on/in which, qua sole basis, a bracelet occurs, then $(\rightarrow)$ the set What on/in which, qua sole basis, a bracelet occurs must possess the basis a qua its sole element; therefore ( $\therefore)$, the basis $a$ and the bracelet $b$ are nothing but the same element.

C. A $\wedge \mathrm{B} \therefore(a=h=b)$, for card $\left({ }_{1} L\right)=1$; i.e., given conditions $\mathrm{A}$ and $\mathrm{B}$, it follows that the basis $a$, the specimen of gold $h$, and the bracelet $b$ are one and the same.

Truth conditions analysis reveals that this first interpretation of ekāśrayasambandha $\left({ }_{1} L\right)$, for card $\left({ }_{1} L\right)=1$, is reducible to coreferentiality (sāmānādhikaranya; $N$ ) between three terms.

[47 e] $\left(\left(a \cdot \boldsymbol{N}_{t}^{(1 L)}\llcorner h)\right\urcorner \boldsymbol{N}^{(1 L)}\llcorner b)\right\urcorner \mathbb{N}\left\llcorner\left(1_{t}\right)\right.$

yat paryāptitvam sāmānādhikaranyatā-avacchedakāvacchinnam tad ekatva-nirūpi-

tam; saiva sāmānādhikaranyatātva-avacchedakāvacchinna-sāmānādhikaranyatā

Footnote 23 continued

very same property from simultaneously being the limitor and the limited (i.e., avacchedaka and avacchinna), through the generation of a further property of different degree (upādhi)—avoids the fallacy called anavasthā or regressus ad infinitum (cf. NK, pp. 19-20; Pellegrini 2016, p. 81). In other terms, the indeterminate base $a$, belonging to the set What on/in which, qua sole basis, at least one instance of goldness occurs, is the base of an occurrence of gold. Nevertheless, this latter set is included in Basis of at least one instance of bracelet-hood. It follows that the indeterminate base $a$ is an element of Basis of bracelet-hood too, according to the general rule: $(x \in \mathrm{A}) \wedge(\mathrm{A} \subseteq \mathrm{B}) \rightarrow(x \in \mathrm{B})$. The relational abstract bracelet-hood-sole-basis-hood (of which the set ${ }_{1} \boldsymbol{L}\left\llcorner b_{t} \mid\right.$, Sole basis of at least an instance of bracelet-hood, is the extension) operates at a more fundamental level than its dependent relational abstract of higher degree 'being gold-ness-sole-basis-hood' (of which the set $\mid{ }_{1} \boldsymbol{L}_{t}\left\llcorner h_{t} \mid\right.$, Being the sole basis of at least one instance of gold-ness, subset of the former, is the extension); its relative defining relational abstract must be 'Being sole-basis-hood' $\left({ }_{1} \boldsymbol{L}_{t}\right)$, since 'Sole-basis-hood' $\left({ }_{\boldsymbol{l}} \boldsymbol{L}\right)$ has already defined the superset Basis of at least one instance of bracelet-hood. Despite the evident cumbersomeness of the expression when translated into natural language, NN technicalities and its formalization in NL thus prove capable of conveying the hierarchy of relations and reference sets with no ambiguities or reflexive drifts. 
hātaka-nirūpitā; saiva avacchedaka-sāmānādhikaranyatātvam anirnīta-sādhāranaáśraya-niștham hätaka-nirūpitam ca; whose purport is ${ }^{(t)}$ 'A specimen of gold is the indeterminate basis $a$, by coreferentiality; a bracelet also is that very basis, since there is but a single object, for $\operatorname{card}(N)=1^{\prime}$.

This interpretation $\left(N^{(1 L)}\right.$; i.e., $N$ as ${ }_{1} L$, for card $\left.\left(N^{(1 L)}\right)=1\right)$ correctly insists on the unity of the referent. Therefore, this common undefined basis which has been here summoned up-i.e., this 'existing $x$ ', according to the s.n. $(\exists x \mid \mathrm{H} x \wedge \mathrm{B} x)$-is revealed to be a third linguistic device (vācārambhaṇa or vāgālambana) distinguishing what de facto is not distinct at all. An additional element of distinction (viz., an undefined basis or $x$ ) is introduced in an attempt to explain the radical unity of two properties. In other words, $1 \mathrm{~L}-\mathrm{Hy}$, as a strategy to circumvent the conundrum about gold and bracelet, plays out a scenario which is even worse than the previous one, displaying three elements (instead of two) and two relations in coordination (instead of one). Worse still is the consequent proliferation (anavastha ) of relations. How, indeed, to connect the first property to its basis if not through another medium, and so on? Thus, $1 \mathrm{~L}-\mathrm{Hy}$, in this last variation, turns out to be if not utterly faulty at least pointless, since the still intact issue of distinction in unity is merely shifted by one step back, ad infinitum. In broader terms, two distinct concurrent logical paradigms are here at stake. According to Nyāya, presuming that an undetermined $x$, qua basis of successive predications or qualifications, is a more primitive notion than an always qualified 'dummy singular term' (Matilal, 1968, p. 23) from which to extract the derived notion of 'undetermined basis', is entirely unjustified. Accordingly, the naiyāyika account requires a single relation only, instead of two, and no abstract particulars (i.e., variables), since only dummy singular terms are postulated, which de facto operate as restricted variables. ${ }^{24}$

\section{Transitional Considerations (6)}

The following passage can be considered as a junction point in the much broader context of VM's rigorous argumentative architecture. Despite all the conceptual difficulties which have been set out so far, a golden bracelet still appears to be a bracelet not less than gold. The relation of coreferentiality thus imposes itself as a primitive and ineliminable notion, both logical and linguistic, a foundational, inescapable, and cognitively irreducible gnoseological framework. ${ }^{25}$ The open

\footnotetext{
24 Regarding restricted variables in NL, cf. Anrò (2022, § 4.2). Regarding the paradox of relations and Bradley's regress in the naiyāyika framework, cf. Id. (2022, fn. 12). Consider also: Plato, Parmenides, 132 $\mathrm{a}-\mathrm{b}$, about the issue of connecting 'what is large' (mégas) with the general property (lit., idea, eidos) of 'largeness' (mégethos); and Aristotle's equivalent third man argument ad Metaphysics, A.9.990b.15-17, A.9.991a.2-5, Z.6.1032a.2-4, Z.13.1039a.2-3, M.4.1079a.11-13, and Sophistic Refutations, XXII.178b36179a 110. Regarding anavasthā cf. fn. 20.

25 Clearly, a primitive notion cannot receive any justification in the context of the logical foundation of a system; on the contrary, it acts as the instrument of demonstration, justification and definition of all the other derived, that is, non-primitive, notions. In this regard, see the analogous primitive concept of 'togetherness' ('W' or 'with') in Goodman (1977, p. 144): "We need, then, a primitive relation that will enable us to differentiate systematically between those classes of qualia that form concreta and those that do not. [...] The basic concreting relation is a symmetric relation of togetherness among qualia. Such a
} 
distinction of multiple properties in the unity of the referent cannot apparently be sublated. VM chooses to quote, at this crucial turning point, a passage from Brahma-sūtra-bhāskāra-bhāsya. Yet let us not be deceived: this is not VM's last word on the issue, but its reaffirmation in ever closer spiral movements.

It is this incontrovertible (abādhita), indubitable (asamdigdha), and universal (sarvajanina), epistemic evidence (pratyaya) of coreferentiality which establishes difference and non-difference between cause and effect. Thereby, since the effects [possess] the same nature (ätman) as their causes, as well as [every] cause always and in every case persists as existent, there is non-difference of the effect-[that is], the phenomenal manifestation-with respect to the reality [of the cause], [not less than] difference [when the former] is considered as effect, such as '[being] a cow, or a pot, etc.' Indeed, it has been said: "Multiplicity qua effect, non-difference qua cause; just as there is nondifference with respect to the gold, but distinction (bhid $\bar{a}$ ) with respect to the earring, and so on". 26

\section{Definition of Difference (7)}

In this respect, it might be said anew: what is this, which is termed difference and should occur in the very same locus (ekatra) together with non-difference? If it [were conceived as] mutual absence (parasparābhāva), would it stand between effect and cause; that is, between bracelet and gold, or would it not? If not, then there would be simple singularity (ekatva), and no difference [at all] (\$7.1). [On the contrary], in case of [mutual absence between bracelet and gold], there would be [full] difference and any [form of] non-difference. Moreover, there would be a [flagrant] contradiction (virodha) between presence and absence: [once that bracelet and gold have been declared as

Footnote 25 continued

relation obtains, for example, between a color and a time or place at which the color occurs: likewise between a place and a time at which the place is presented. In general, it obtains between any two atomic qualia belonging to some one concretum". Regarding the process of gnoseological justification, performed by means of successive increments, from jũāna ("cognition"), via pramā ("raw knowledge"), to nirnaya and siddhānta ("knowledge self-consciously certified"), see Phillips (2012, pp. 4-5).

26 VM-B (2018, pp. 72-73): so 'yam abādhito 'saṃdigdhaḥ sarvajanīnah sāmānādhikaranyapratyaya eva kāryakāraṇayor bhedābhedau vyavasthāpayati | tathā ca kāryāṇām kāraṇātmatvāt, kāraṇasya ca sadrūpasya sarvatrānugamāt, sadrūpeṇābhedạ kāryasya jagatah, bhedah kāryarūpena goghatādineti | yathāhuh kāryarūpena nānātvam abhedah kāranātmanā | hemātmanā yathābhedah kuṇ̣̂alādyātmanā bhidā || iti I. Śāstrī\&Raja (VM-B 1933, pp. 176) opportunely translate pratyaya as 'appositional cognition'. Nevertheless, in order to avoid any possible suspicion of superimposition or false attribution (adhyāsa), I prefer to discard this term. Regarding 'apposition', see Partridge (1966, p. 2507) and Glare (1968, pp. 1401-1402): "pōno, pōnere [...] to place [...], to put in position [...], to lay [...], to put or cast [...]". I propose instead the locution 'epistemic evidence', according to its Latin etymology; cf. Partridge (1966, pp. 1008, 3694) and Glare (1968, p. 626): "éuidentia, [...] the quality of being manifest [...], obviousness" and "éuidens, [...] perceptible [...], clear [...], open, unconcealed [...]". Regarding the passage quoted by VM, cf. BSBhB (1991, p. 18): kāryarūpeṇa nānātvam abhedah kāraṇātmanāa hemātmanā yathābhedạ̣ kuṇdalādyātmanā bhidā || iti | vedāntanipuṇammanya kaścid āha |. Cf. Agrawal-Potter (2013, pp. 33-36, 42-46, 113-172); Dasgupta (1961, p. 329). 
mutually excluding, their] co-presence (saha-avasthāna) is [clearly] impossible (asambhava) (\$7.2.1). Alternatively, in the case [the co-presence of mutually exclusive properties were said to be] possible, the undesired consequence (prasanga) of an in rem (tattva) non-difference between a bracelet and a vardhamanna [would inevitably follow], due to the lack of contradiction between difference and non-difference (\$7.2.2). ${ }^{27}$

VM here examines in detail the features of difference (bheda) as mutual absence (parasparābhāva or anyonyābhāva, I). A pot, for instance, is mutually absent with respect to a cloth simply because where there is a pot there is not a cloth, and vice versa (for $\mathrm{G} \cap \mathrm{P}=\varnothing$, i.e., 'the intersection between Pots and Cloths is empty). Now, VM sharply asks, does this mutual absence-which is reducible, salva veritate, to the constant or absolute absence of identity (tādātmya-atyantābhāva, $\nexists(I)$; cf. P2.§3. [19]-[21])—also occur between non-identical coreferential properties, such as goldness and bracelet-hood?

\section{Absence of Difference as Mutual Exclusion (7.1)}

In a first case, VM suggests, difference qua mutual absence (anyonyābhāva) might be straightforwardly negated; that is, declared as absolutely absent (atyantābhāva). Provided that hattakam kațakam ('The bracelet is gold'), its negation should in turn be negated, i.e., hätakam na katakam ity na ('It is false that a bracelet is not gold'):

$$
\begin{aligned}
& {\left[48_{\mathrm{a}}\right] h \rightleftharpoons \nexists^{-\mathbf{1}}\left\llcorner\left(\nexists _ { t } ^ { - 1 } \left\llcorner\left(\boldsymbol{\Gamma}^{\mathbf{1}}\llcorner b)\right)\right.\right.\right.} \\
& \text { yā hātaka-niștha-atyantābhāvīya-pratiyogitā sā atyantābhāvīya-pratiyo- } \\
& \text { gitātva-nirūpitā, saiva atyantābhāvīya-pratiyogitātvam tādātmyatā-nirūpitam, } \\
& \text { saiva tādātmyatā kațaka-nirūpitā, tadviparyayeṇa ca; 'Constant absentee- } \\
& \text { hood, conditioned by being constant absentee-hood in turn conditioned by } \\
& \text { identity conditioned by a bracelet, occurs in a specimen of gold, \&vv'; that is, } \\
& { }^{(t)} \text { 'A bracelet is not not-gold'; iff } h \notin\left|\nexists^{-\mathbf{1}} \mathbf{L}\left(\boldsymbol{\Gamma}^{\mathbf{1}} \mathbf{L} b\right)\right| \wedge b \notin \mid \nexists^{-\mathbf{1}} \mathbf{L}\left(\boldsymbol{\Gamma}^{\mathbf{1}}\llcorner h) \mid\right. \text {; i.e. 'A } \\
& \text { specimen of gold does not belong to the set What is absent with respect to } \\
& \text { identity with a bracelet, \&vv'. }
\end{aligned}
$$

\footnotetext{
27 VM-B (2018, p. 73): atrocyate kah punar ayam bhedo nāma, yah sahābhedenaikatra bhavet | parasparābhāva iti cet, kim ayam kāryakāraṇayoh kațakahāțakayor asti na vā | na cet, ekatvam evāsti, na ca bhedaḥ | asti ced bheda eva nābhedah $\mid$ na ca bhāvābhāvayor avirodhah, sahāvasthānāsambhavāt $\left(^{\#}\right) \mid$ sambhave vā kațakavardhamānayor $\left(^{\circ}\right)$ api tattvenābhedaprasañgah, bhedasyābhedāvirodhāt $\mid . \quad\left(^{\#}\right)$ Double negation; lit.: "there is not (na ca) a non-contradiction (a-virodha) between presence and absence"; ergo, "there is a contradiction". ( $\left.{ }^{\circ}\right)$ Śāstrī\&Raja (VM-B 1933, p. 286, fn. 118) suggest that a "vardhamāna would appear to have been a gold ornament in the form of a svastikä"; Ranganath (1999, p. 325) follows this interpretation. In his commentary to VM-B, Amalānanda (1895, pp. 70-71) makes no mention of it. In MW $(926,1)$ and B (VI, 36), the only compatible definitions with Śāstrī\&Raja's suggestion are respectively: "a kind of mystical figure or diagram" (if a golden one) and "eine Schüssel von best" (a bowl or dish, if golden). The first among the incompatible meanings is instead, Ricinus Communis or castor-oil plant. Yet, the overall message is clear: the first case implies a sāmānädhikaranya relation-since, whatever it is, a vardhamāna is nothing but a golden artifact; the second case is fully reducible to a simple relation of atyantābheda, whose meaning parallels the utter difference between a cow and a horse (cf. supra, §5).
} 
In a second step, provided that $\nexists(I)=t$ (i.e., tādātmyātyantābhāva = anyonyābhāva; cf. supra), by means of the transition formula $\left[48_{\mathrm{b}}\right] h \rightleftharpoons \nexists^{-1}\left\llcorner\left(I^{-1}\llcorner b)\right.\right.$, the counterfactual formula is then newly obtained and reconfirmed, expressing the relation of non-difference between gold and bracelet: [44] $\left(\left(\left(h . N\left\llcorner\llcorner) \rightleftharpoons \nexists^{-1}\left\llcorner\left(\boldsymbol{F}^{-1}\llcorner b)\right) \neg N\left\llcorner\left(I_{t}\right)\right.\right.\right.\right.\right.\right.$, i. e., (t) A specimen of gold is not the counterpositive of a difference with regard to a bracelet, being the former coreferential to the latter, for a cardinality equal to one'clearly matching the model of Gadādhara's definition of unity (ekatva; cf. P2 f.[22][24], [34]). Let us deepen further the analysis of its truth conditions:

A. $h \notin \mid \boldsymbol{F}^{-1}\left\llcorner b|\wedge b \notin| \boldsymbol{F}^{-1}\llcorner h \mid\right.$, i.e, 'A specimen of gold does not belong to the set What is different from a bracelet, \&vv'; ergo: $h \notin \overline{\mathrm{B}^{\prime}}$ (for $\mid \boldsymbol{F}^{-1}\left\llcorner b \mid=\overline{\mathrm{B}^{\prime}}\right.$ ); that is, ' $h$ does not belong to the complement of $\mathrm{B}^{\prime}$ (for $\mathrm{B}^{\prime}=\{b\}$; the singleton 'A certain bracelet' containing $b$ only)'; in parallel, $b \notin \overline{\mathrm{H}^{\prime}}$ (for $\mid \boldsymbol{F}^{-1}\left\llcorner h \mid=\overline{\mathrm{H}^{\prime}}\right.$ ) ' $b$ does not belong to the complement of $\mathrm{H}^{\prime}$ (for $\mathrm{H}^{\prime}=\{h\}$; the singleton 'A certain specimen of gold' containing $h$ only)'; therefore, the linguistically divergent expressions ' $h$ ' and ' $b$ ' refer to the same referent or singular extension $(h=b$, according to the distinction arthatah and śabdatah, or names vs. mentions; cf. P2.§3), for ( $h$, b) $\in \mathrm{B}^{\prime}$ and $\operatorname{card}\left(\mathrm{B}^{\prime}\right)=1$, or $(h, b) \in \mathrm{H}^{\prime}$ and $\operatorname{card}\left(\mathrm{H}^{\prime}\right)=1$.

B. If condition $\mathrm{A}$, then: $h \in \mathrm{B}^{\prime}$ (for $\left.\mathrm{B}^{\prime}=\{b\}\right) \wedge b \in \mathrm{H}^{\prime}$ (for $\mathrm{H}^{\prime}=\{h\}$ ); i.e., ' $h$ belongs to the singleton containing $b$ only', as well as ' $b$ belongs to the singleton containing $h$ only'. Conditions A and B clearly show that [44] is indeed a perfect case of sāmānādhikaranya, for card $(N)=1$ and $V^{(N)}: \mathrm{B} \mapsto V^{(N)}[\mathrm{B}]$ and $V^{(N)}[\mathrm{B}] \subseteq \mathrm{B}$, in virtue of SVN (cf. P1.§4, P2.§4).

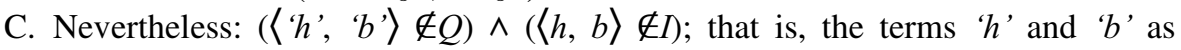
mentions are linguistically divergent, being expressions of distinct (i.e., not coextensive) properties (for $\mathrm{H} \neq \mathrm{B}$, and $\mathrm{H} \cap \mathrm{B} \neq \varnothing$ ) (cf. P2.[28]). Thus, by the application of TKN (cf. §5.1), the occurrences $h$ and $b$ of the properties $\left|h_{t}\right|=\mathrm{H}$ and $\left|b_{t}\right|=\mathrm{B}$ cannot be said stricto sensu to be identical (since the plexus of properties, in case of identity, must appear indiscernible). Indeed, [44] is neither ruled by LL (Leibniz's Law), nor can pass the ST (substitutivity Test) (cf. P2.§4).

The first hypothesis analysed by VM, i.e., the negation of difference qua reciprocal absence, turns out to be an attestation of unity (ekatva) between the relata. It should also be noted how VM cautiously and subtly employs the term 'unity' and avoids awkwardly evoking here the term 'identity' (tādātmya; cf. P2.§4).

\section{Difference as Mutual Exclusion (7.2.1)}

The discussion of the second possibility is far easier. As it has already been said, if there is mere mutual exclusion between bracelet $(b)$ and gold $(h)$, there will be simple difference between them; in other words, any form of non-difference, just as in the case of cow-hood and horse-hood (cf. §5). On the model of P2.[21], a relation of mutual exclusion regarding $b$ and $h$-highlighting its cardinality and again 
interpreting difference as absence of identity $(I=\nexists(I))$ qua case of coreferentiality $\left(N^{(I)}\right.$; i.e., $N$ as $I$, for $\left.I \subseteq N\right)$ — can be expressed in NL as:

$$
*\left[49_{\mathrm{a}}\right]\left(h . \nexists^{-1}\left\llcorner\left(\boldsymbol{N}^{(I)}\llcorner b)\right)\right\urcorner \mathbb{N}\llcorner(2))\right.
$$

yat paryāptitvaị atyantābhāvīya-pratiyogitā-avacchedakāvacchinnam tad dvitva-nirūpitam, saiva hātaka-niștha-atyantābhāvīya-pratiyogitā sāmānādhikaranyatā-nirūpitā, saiva sāmānādhikaranyatā kațaka-nirūpitā; whose purport is ${ }^{(t)}$ 'A specimen of gold $(h)$ and a bracelet $(b)$ are different, namely, noncoreferential, since they are two distinct objects'; iff $h \in\left(\left|h_{t}\right|=\mathrm{H}\right) \wedge b \in\left(\left|b_{t}\right|=\mathrm{B}\right)$; $h \notin \mid N\llcorner b \mid$ (i.e., ' $h$ does not belong to the set What is coreferential to $b$ '); card $(\{h, b\})=2$ (i.e., 'The set containing $h$ and $b$ as its elements has a cardinality equal to two'); in s.n. ( $\exists x, \exists y \mid \mathrm{H} x, \mathrm{~B} y)$; that is, 'There is a specimen of gold, as well as, there is a bracelet'.

Nevertheless, formula $*\left[49_{\mathrm{a}}\right]$ is utterly false, since in plain contradiction with the adopted premise (cf. [44]) according to which a golden bracelet is a radically single object. In the words of VM, whether golden bracelet and gold were conceived as mutually excluding, "there would be a [flagrant] contradiction between presence and absence", since their co-presence (saha-avasthāna) would be simultaneously possible and impossible. In sum, if it is false that $*\langle h, b\rangle \in t$ (i.e., ' $h$ and $b$ do not constitute an ordered pair of mutual absence relation'); yet, salva veritate, it is true that: $\nexists(I)=\nexists(\nexists(I))=z$ (i.e., 'The relation of absence of mutual absence shares the same ordered pairs with the relation of absence of absence of identity; that is, nondifference'). Therefore: $\langle h, b\rangle \in \in(\nexists(I)=\nexists(\nexists(I))=z)$ (i.e., ' $h$ and $b$ constitute an ordered pair of the relation of absence of mutual absence, or absence of absence of identity, or non-difference).

\section{Coexistence in Difference as Mutual Absence (7.2.2)}

VM then introduces a further slight change of perspective according to which the properties gold-ness and bracelet-hood are said to be forcefully coexistent (sahāvasthāna), i.e., coreferential $(N)$, despite the fact that they have been here considered as reciprocally absent by hypothesis (cf. §7.2.1). In other words, VM argues, it could still be argued that these two properties might somehow be forced to coexist despite their neat reciprocal distinction. ${ }^{28}$ In a complementary manner, this line of argumentation is premised on the assumption that the supposedly coreferential properties gold-ness and bracelet-hood could appear, nevertheless, as mutually absent. Thus, generalizing $*\left[49_{\mathrm{a}}\right]$, the following universal assertion will first be obtained:

$$
*\left[49_{\mathrm{b}}\right] h_{t} \rightleftharpoons \nexists^{-1} \mathrm{~L}\left(\Gamma^{-1}\left\llcorner b_{t}\right)\right.
$$

yā hātakatva-avacchedakāvacchinna-atyantābhāvīya-pratiyogitā sā tādātmyatā-nirūpitā, saiva tādātmyatā katakatva-nirūpitā, tadviparyayena ca; that is, ${ }^{(t)}$ 'Every specimen of gold and every bracelet is mutually absent'; iff *((|

\footnotetext{
${ }^{28}$ It is clear that my choice to interpret, as already declared, co-existence qua coreference has no alternative. All weaker possible solutions-such as, the relations of substratutm-superstratum or 'residing on the very same basis'-have already been excluded (cf. supra §5).
} 
$\left.\left.h_{t}|\cap| b_{t} \mid\right)=*(\mathrm{H} \cap \mathrm{B})\right)=\varnothing$ ('The intersection between Gold and Bracelets is empty'); in s.n.: $(\exists x, \exists y \mid \mathrm{H} x, \mathrm{~B} y)$ ('There is a specimen of gold and a bracelet').

In the same manner, let us now consider the relation standing between the properties bracelet-hood $\left(b_{t}\right)$ and being a vardhamāna (vardhamānatva, $v_{t}$ ). Whatever a vardhamāna is-whether it is a golden ornament or a completely different thing, such as a castor-oil plant (cf. fn. 27) - it must be said to be distinct from a bracelet beyond any doubt, since there is no bracelet which is also a vardhamāna and vice versa. Therefore:

[49 $] v_{t} \rightleftharpoons \nexists^{-1} \mathrm{~L}\left(\boldsymbol{\Gamma}^{\mathbf{1}}\left\llcorner b_{t}\right)\right.$

yā vardhamānatva-avacchedakāvacchinna-atyantābhāvīya-pratiyogitā $\quad s \bar{a}$

tādātmyatā-nirūpitā, saiva tādātmyatā kațakatva-nirūpitā, tadviparyayeña ca; that is, ${ }^{(t)}$ 'Bracelets and vardhamānas (v) are always mutually absent'; iff $b \in(\mid$ $\left.b_{t} \mid=\mathrm{B}\right) \wedge v \in\left(\left|v_{t}\right|=\mathrm{V}\right) \wedge(\mathrm{B} \cap \mathrm{V}=\varnothing)$ ('The intersection between Bracelets and Vardhamānas is empty'); in s.n.: $(\exists x, \exists y \mid \mathrm{B} x, \mathrm{~V} y)$ (i.e., 'There is a bracelet and there is a vardhamāna').

Under this hypothesis it must, in parallel, be admitted that gold and bracelet are forcefully coexistent (sahāvasthāna). That means that coreferentiality $(N)$ must stand between them as an imposed condition. As already expressed in [44] $\left(\left((h . N \circ b) \rightleftharpoons \nexists^{\mathbf{1}}\left\llcorner\left(\boldsymbol{F}^{\mathbf{1}}\llcorner b)\right) \neg \mathbb{N}\left\llcorner\left(l_{t}\right)\right.\right.\right.\right.$, it must be admitted that: $h \in \mid \boldsymbol{N}\llcorner b \mid$ ( 'A specimen of gold belongs to the set What is coreferential to a bracelet' $), h \in\left(\left|h_{t}\right|=\mathrm{H}\right), b \in\left(\left|b_{t}\right|=\mathrm{B}\right)$, and $\mathrm{H} \cap \mathrm{B} \neq \varnothing$. Now, following VM here, the patent contradiction between the respective truth conditions (viz., $*\left[49_{b}\right]$ for $\mathrm{H} \cap \mathrm{B}=\varnothing$ and [44] for $\mathrm{H} \cap \mathrm{B} \neq \varnothing$ ) be momentarily left aside, to firstly focus on the fact that $*\left[49_{\mathrm{b}}\right] h_{t} \rightleftharpoons \nexists^{-\mathbf{1}}\left\llcorner\left(\boldsymbol{\Gamma}^{\mathbf{1}}\left\llcorner b_{t}\right)\right.\right.$ and [49 $\mathrm{c}] v_{t} \rightleftharpoons \nexists^{-1}\left\llcorner\left(\Gamma^{\mathbf{1}}\left\llcorner b_{t}\right)\right.\right.$ are formally identical. Therefore, once it has been accepted that gold and bracelet can be said to be forcefully coexistent (sahāvasthāna, via $N$; in compliance with [44]) despite the fact that their respective properties are mutually absent (in compliance with $*\left[49_{b}\right]$ ), how then might it be possible to prevent that a bracelet and a vardhamāna could also be coreferential in the same manner, although it is patently absurd (as stated in [49 $]$ ) that a bracelet could also be a vardhamāna, and vice versa? To put it another way, if $*\left[49_{\mathrm{b}}\right] h_{t} \rightleftharpoons \nexists^{-\mathbf{1}}\left\llcorner\left(\Gamma^{-1}\left\llcorner b_{t}\right)\right.\right.$, and nevertheless $h \in \mid N\llcorner b \mid$ (as in [44]) then also $* b \in \mid N\llcorner v \mid$, for $\mathrm{B} \cap \mathrm{V} \neq \varnothing$, despite the fact that $\left[49_{\mathrm{c}}\right] v_{t} \rightleftharpoons \nexists^{-\mathbf{1}} \mathrm{L}\left(\boldsymbol{\Gamma}^{\mathbf{1}}\left\llcorner b_{t}\right)\right.$, for $\mathrm{B} \cap \mathrm{V}=\varnothing$. As expected, VM says the hypothesis under $\$ 7.2 .2$ cannot but lead to the "undesired consequence of an in rem (tattva) non-difference between a bracelet and a vardhamāna". In other words, if the principle is accepted according to which difference qua mutual absence can be compatible, no matter how, with non-difference qua coreferentiality, nothing could then prevent the application of this very same relation to any other property. Each property might thus be said to be coexistent with every other. Therefore, if gold-ness and bracelet-hood are clearly distinct properties, their manner of not being equal and identical (i.e., coextensive, cf. P2) is never reducible to that existing between bracelet-hood and vardhamānatva (i.e., anyonyābhāva); or, roughly speaking, a bracelet differs from the gold of which it is made in a different way from the manner a pot differs from a horse. VM definitely shows that an imposed compatibility, 
coordination, or coexistence in mutual absence cannot apply to abheda, since this latter would then be jeopardized by the definitional flaw of over-application (ativyāpti-doșa-lakșana; cf. fn. 7). This unreflecting form of irenic non-contradiction between difference and non-difference, according to which mutually exclusive properties can supposedly coexist, being applicable to every case of difference, cannot but generate an unstoppable general escalation of "undesired consequences". Since coexistence occurs only under certain conditions (e.g., between pot and clay, but never between lake and fire) the alleged solution of an unspecified coexistence of bhedābheda-'bheda together with abheda', respectively conceived as mutual absence and negation of mutual absence-is unavoidably dismissed. ${ }^{29}$

\section{The Undesired Obliteration of Every Concurrent Property (8)}

Moreover, in [the hypothesis where] a bracelet is not different from the gold [of which it is made, not being the former the counterpositive of a mutual absence with respect to the latter], [also all other golden] bracelets, crowns, earrings, etc., should not be distinguishable from gold. In the same manner, they could never be distinguished from [that first] bracelet, [as well as one from another], by virtue of their [acknowledged] non-difference from gold. Consequently, [according to this hypothesis], gold only [could be properly assessed as the unquestionable] reality of [all those] beings (vastu-sat), [and surely] not [their 'being] bracelets', and so on, [that we are instead forced to acknowledge as gold solely]. [This is simply] because difference, [so conceived], would not appear [in any form between gold and golden artifacts, as well as between golden artifact and golden artifact]. It follows that, [along these lines, we are once again brought back to the starting point]: there is nondifference only with respect to the gold, [but] not with respect to the bracelet - since this latter is [undoubtedly] different from an earring, etc. ${ }^{30}$

In this passage VM has again slightly changed his perspective through the introduction of a multiplicity of distinct specimens of gold. A first strand of objections has been completely exhausted. Indeed, since the mutual absence between gold and bracelet, as well as the coexistence of their mutual absence with their coreferentiality, have both been dismissed, it only remains to accept their nondifference; that is, the negation of their mutual absence (anyonyābhāvaatyantābhāva; $\nexists(\nexists)$; cf. §7). Thus, it is here no longer a matter of distinguishing

\footnotetext{
${ }^{29}$ The ambiguity regarding the translation of the term 'vardhamāna', which at first glance might be seen as a flaw, reveals itself to be an unexpected advantage (cf. fn. 27), providing us with a simultaneous double reading. In the case a vardhamāna were a golden artifact then it would be utterly analogous to the bracelet instance, for $\mathrm{H} \cap \mathrm{V} \neq \varnothing$, but $\mathrm{B} \cap \mathrm{V}=\varnothing$. In contrast, if a vardhamāna were something completely different from gold, e.g., a castor-oil plant, then it would be another image of absolute distinction, as in the case of gold and cows, for $\mathrm{H} \cap \mathrm{V}=\varnothing$, as well as $\mathrm{B} \cap \mathrm{V}=\varnothing$.

30 VM-B (2018, p. 73): api ca kațakasya hāṭakād abhede yathā hātakātmanā kațakamukuṭakuṇdalādayo na bhidyante evam kațakātmanāpi na bhidyeran, kațakasya hāțakād abhedāt | tathā ca hātakam eva vastusat na kațakādayah, bhedasyāpratibhāsanāt | atha hāțakatvenaivābhedo na kațakatvena, tena tu bheda eva kuṇdalādeh $\mid$.
} 
the bracelet from the gold of which it is made, but of possibly differentiating one golden artifact from another one, in consideration of the fact that they are all nothing but gold. In the light of the fact that the gold is neither identical nor mutually absent with regard to the bracelet, what is the relation between a golden bracelet and a golden crown?

In order to answer this question, let us first consider in more detail the truth values of formula P2.[44] $\left(\left(\left(h \cdot N\left\llcorner\llcorner b) \rightleftharpoons \nexists^{-1}\left\llcorner\left(\boldsymbol{F}^{-1}\llcorner b)\right) \neg \mathbb{N}\left\llcorner\left(I_{t}\right),{ }^{(t)}\right.\right.\right.\right.\right.\right.$ 'A bracelet $(b)$ is nondifferent from a specimen of gold $(h)^{\prime}$ :

A. $h \notin \overline{B^{\prime}}$; i.e., 'A specimen of gold does not belong to the complement of the singleton $A$ certain bracelet', for $\overline{\mathrm{B}^{\prime}}=\mid \boldsymbol{\Psi}^{-1}\llcorner b \mid$; i.e., 'The complement of the singleton $A$ certain bracelet $=$ What is not identical to a certain bracelet';

B. $h \notin \overline{B^{\prime}} \rightarrow h \in \mathrm{B}^{\prime}$, for card $\left(\mathrm{B}^{\prime}\right)=1$, since $\mathrm{B}^{\prime}=\{b\}$; that is, 'If condition $\mathrm{A}$, then a specimen of gold belongs to the singleton $A$ certain bracelet, for cardinality equal to one, since the singleton $A$ certain bracelet possesses only a certain bracelet as its element';

C. $*\langle h, b\rangle \in I \wedge(h, b) \in \mathrm{B}^{\prime}$, for $\operatorname{card}\left(\mathrm{B}^{\prime}\right)=1$; i.e., 'A specimen of gold and a bracelet do not satisfy the relation of identity; nevertheless, being the very same object, they both belong to the same singleton'.

Nonetheless, it is likewise true that other gold artifacts do exist indeed, such as crowns $(m)$. It will be thus symmetrically obtained:

$\left[50_{\mathrm{a}}\right]\left(\left(\left(h^{l} . \boldsymbol{N}\llcorner m) \rightleftharpoons \nexists^{-1}\left\llcorner\left(\boldsymbol{I}^{-1}\llcorner m)\right) \neg \mathbb{N}\left\llcorner\left(1_{t}\right)\right.\right.\right.\right.\right.$

yad atyantābhāvīyapratiyogitā-avacchedakāvacchinna-paryāptitvam tad ekatvanirūpitam; tatra yaiva atyantābhāvīyapratiyogitā hātaka-niștha-mukuṭa-nirūpitasāmānādhikaranyatā-avacchedakāvacchinnā sā anyonyābhāvīyapratiyogitā-nirūpitā, eșaiva anyonyābhāvīyapratiyogitā mukuț-nirūpitā, tadviparyayeṇa ca; ${ }^{(t)}$ 'A crown $(m)$ is not the counterpositive of a difference with respect to a specimen of gold'; iff:

A. $h^{l} \in\left(\left|h_{t}\right|=\mathrm{H}\right) \wedge m \in\left(\left|m_{t}\right|=\mathrm{M}\right)$, for TvN; that is, 'A specimen of gold belongs to the set Gold', and 'A crown belongs to the set Crowns';

B. $h^{l} \notin \overline{M^{\prime}}$; i.e., 'A specimen of gold does not belong to the complement of the singleton $A$ certain crown' (for $\overline{\mathrm{M}^{\prime}}=\mid \boldsymbol{F}^{-1}\llcorner m \mid$, 'The complement of the singleton $A$ certain crown $=$ What is not identical to a certain crown');

C. $h^{l} \notin \overline{M^{\prime}} \rightarrow h^{1} \in \mathrm{M}^{\prime}$, for card $\left(\mathrm{M}^{\prime}\right)=1$, since $\mathrm{M}^{\prime}=\{m\}$; that is, 'If condition $\mathrm{B}$, then a specimen of gold belongs to the singleton A certain crown, for cardinality equal to one, since the singleton $A$ certain crown possesses only a certain crown as its element';

D. $*\left\langle h^{1}, m\right\rangle \in I \wedge\left(h^{1}, m\right) \in \mathrm{M}^{\prime}$; i.e., 'A specimen of gold and a crown do not satisfy the relation of identity; nevertheless, being the very same object, they both belong to singleton $A$ certain crown'. 
In order to make all the features of this new perspective explicit, along with all its related difficulties, the notion of cardinality of a relation will once again prove helpful. At its simplest, the key point regarding the preceding provisional premises - $[44]$ and $\left[50_{\mathrm{a}}\right]$ - is that two alternative scenarios are here at stake: ultimately, either it comes down to the admission that there is only one indistinguishable occurrence of gold (i.e., $h=h^{1}$ ), which is nonsensical, or that there are distinct and distinguishable ones (i.e., $h \neq h^{l}$ ).

\section{'This Very Same Thing' (8.1)}

In a first possibility, let us assume that the gold-which is non-different from the crown, being the latter nothing but gold-is also not-differentiable from a bracelet, which is equally made of gold. Thereby, nothing less and nothing more than an instance of gold, not further specified, is here referred to. According to this first configuration, through the combination of [44] and [50 3 truth values, the following will be obtained:

A. (*) $h=h^{1}$; in the meaning of: $\left\langle h, h^{l}\right\rangle \in I$, that is, ' $h$ and $h^{l}$ are identical, being the very same specimen of gold', since no other property is here available in order to make a further distinction;

B. (*) $h \notin \overline{\mathrm{B}^{\prime}}$ (for $\mid \boldsymbol{F}^{-1}\left\llcorner b \mid=\overline{\mathrm{B}^{\prime}}\right) \wedge h^{1} \notin \overline{\mathrm{M}^{\prime}}$ (for $\mid \boldsymbol{F}^{-1}\left\llcorner b \mid=\overline{\mathrm{M}^{\prime}}\right.$ ); respectively: 'A specimen of gold does not belong to the complement of the singleton $A$ certain bracelet (for: complement of singleton $A$ certain bracelet $=$ What is not identical to $a$ certain bracelet)'; in parallel, 'A specimen of gold does not belong to the complement of the singleton A certain crown' (for: complement of singleton $A$ certain crown $=$ What is not identical to a certain crown)';

C. $\left(^{*}\right)\left(h \notin \overline{B^{\prime}} \wedge h^{l} \notin \overline{M^{\prime}}\right) \rightarrow\left(h \in \mathrm{B}^{\prime} \wedge h^{1} \in \mathrm{M}^{\prime}\right)$ (for: $\operatorname{card}\left(\mathrm{B}^{\prime}\right)=1, \mathrm{~B}^{\prime}=\{b\}$; and card $\left.\left(\mathrm{M}^{\prime}\right)=1, \mathrm{M}^{\prime}=\{m\}\right)$; i.e., if condition $\mathrm{B}$, then 'A specimen of gold belongs to the singleton $A$ certain bracelet' (for a cardinality equal to one, since this singleton contains only one bracelet); in parallel, 'A specimen of gold belongs to the singleton $A$ certain crown' (for a cardinality equal to one, since this singleton contains only one crown);

D. (*) $\left(h \in \mathrm{B}^{\prime} \wedge h^{1} \in \mathrm{M}^{\prime}\right) \rightarrow\left((h, b) \in \mathrm{B}^{\prime} \wedge\left(h^{1}, m\right) \in \mathrm{M}^{\prime}\right)$; that is, if condition $\mathrm{C}$, then 'A specimen of gold and a certain bracelet belong to the same singleton $A$ certain bracelet'; in parallel, 'A specimen of gold and a certain crown belong to the same singleton $A$ certain crown';

E. $(*)\left(h=h^{1}\right) \wedge\left((h, b) \in \mathrm{B}^{\prime} \wedge\left(h^{1}, m\right) \in \mathrm{M}^{\prime}\right) \rightarrow\left(\left(h=h^{l}\right), b, m\right) \in\left(\mathrm{M}^{\prime}=\mathrm{B}^{\prime}\right)$; i.e., if condition $\mathrm{A}$ and condition $\mathrm{D}$, then 'A specimen of gold, a bracelet and a crown belong the to the singleton $A$ certain crown, which coincides with the singleton $A$ certain bracelet'.

In other words, if the specimen of gold which is not the counterpositive of a difference with respect to a bracelet (since, according to $N$, it is the same single object) is indistinguishable from the specimen of gold which in turn is not the counterpositive of a difference with respect to a crown, then nothing can prevent that the bracelet and crown themselves turn out to be one and the same: 
${ }^{*} m \rightleftharpoons \nexists^{-1}\left\llcorner\left(\boldsymbol{I}^{-1}\llcorner b)\right.\right.$; that is, *'A bracelet is not the counterpositive of a difference with respect to a crown'. Thereby, mukutam katakam (*m.N $\mathrm{L} b$, or *'A bracelet is a crown'), which is plainly absurd. As expected, under this hypothesis, every relatum collapses into the identity of a single object. If that were the case, the state of affairs termed as 'double occurrence' (cf. §5.1) would reappear in a possibly even more arguable version: so to speak, in a sort of 'double double occurrence' or dvidviravabhāsa. In point of fact, the only acknowledgeable difference would be here the introduction of a third element, the crown, qua relational medium between gold and bracelet. Thus, according to the pattern of a repeated double occurrence: if $*\langle h, b\rangle \in I$, then $\langle h, h\rangle \in I$; if $*\langle h, m\rangle \in I$, then $\langle h, h\rangle \in I$; ergo, $*\langle b, m\rangle \in I$, since anew $\langle h$, $h\rangle \in I$. That is: $[a]$ a bracelet is non-different from a specimen of gold, it is thus *identical to that specimen of gold; therefore, a specimen of gold is identical to a specimen of gold; $[b]$ a crown is non-different from a specimen of gold, it is thus *identical to that specimen of gold; thereby, a specimen of gold is thus identical to itself; $[c]$ starting from these premises, it follows that *'A bracelet is identical to a crown', by virtue of the fact that 'A specimen of gold is identical to itself'. Nevertheless, as with the options already discarded, there is no more room for any supposed substitutivity between indiscernibles or for a generic application of transitivity (cf. TKN; $§ 5.1$ ).

\section{Distinct Specimens of Gold (8.2)}

In a second possibility, that gold which is non-different from the bracelet is more suitably said not to be the very same gold of which the crown is made. Since two distinct specimens of gold are here at stake, the cardinality of the relata under exam consequently increases to two. It follows that:

A. $h \neq h^{1}$; i.e., $h$ and $h^{1}$, in formulae [44] and [50, ], are distinct specimens of gold;

B. $h \notin \overline{\mathrm{B}^{\prime}}\left(\right.$ for $\mid \boldsymbol{F}^{-1}\left\llcorner b \mid=\overline{\mathrm{B}^{\prime}}\right) \wedge h^{l} \notin \overline{\mathrm{M}^{\prime}}$ (for $\mid \boldsymbol{F}^{-1}\left\llcorner b \mid=\overline{\mathrm{M}^{\prime}}\right)$ (cf. $\S 8.1$, condition B);

C. $\left(h \notin \overline{\mathrm{B}^{\prime}} \wedge h^{l} \notin \overline{\mathrm{M}^{\prime}}\right) \rightarrow\left(h \in \mathrm{B}^{\prime} \wedge h^{l} \in \mathrm{M}^{\prime}\right)$; for: $\operatorname{card}\left(\mathrm{B}^{\prime}\right)=1, \mathrm{~B}^{\prime}=\{b\}$, and card $\left(\mathrm{M}^{\prime}\right)=1, \mathbf{M}^{\prime}=\{m\}$ (cf. $\S 8.1$, condition $\left.\mathrm{C}\right)$;

D. $\left(h \neq h^{1}\right) \wedge\left(h \in \mathrm{B}^{\prime} \wedge h^{1} \in \mathrm{M}^{\prime}\right) \rightarrow\left(b \in \mathrm{B}^{\prime}\right) \neq\left(m \in \mathrm{M}^{\prime}\right)$; that is, if $h$ and $h^{1}$ are distinct specimens of gold which respectively belong to the singletons $A$ certain bracelet and $A$ certain crown, then the bracelet which belongs to the singleton $A$ certain bracelet is different from the crown which belongs to the singleton $A$ certain crown;

E. $\left(b \in \mathrm{B}^{\prime}\right) \neq\left(m \in \mathrm{M}^{\prime}\right) \rightarrow\langle b, m\rangle \notin N$; that is, if the bracelet which belongs to the singleton $A$ certain bracelet is different from the crown which belongs to the singleton $A$ certain crown, then the bracelet and the crown are not coreferential;

F. $\langle b, m\rangle \notin N \rightarrow \operatorname{card}\left(\mathrm{B}^{\prime}, \mathbf{M}^{\prime}\right)=2$; that is, the bracelet and the crown are not coreferential, the cardinality of the singletons $A$ certain bracelet and $A$ certain crown is equal to two. 
In the case where the bracelet and the crown appear as distinct occurrences of the property gold-ness, then those very bracelet and crown, which in themselves are nothing but instances of gold, turn out to be two distinct objects, reciprocally disjunct and not coreferential at all. This condition, in point of fact, opens a new scenario. Although not mutually coreferential, both the bracelet and the crown are not to be considered the counterpositive of a difference with respect to the property gold-ness (cf. [44] and [50 $]$ ]). From this, it might be provisionally deduced that only gold is what exists here (vastusat), by reason of the obliteration or "lack of manifestation" (a-pratibhāsana) of every other concurrent qualification, with respect to the two occurrences of gold-ness which are here at stake. In consideration of the fact that solely the property gold-ness is involved for the time being, the following state of affairs clearly emerges: $\left(b \in\left(\left|h_{t}\right|=\mathrm{H}\right)\right) \wedge\left(m \in\left(\left|h_{t}\right|=\mathrm{H}\right)\right)$, for $\mathrm{H}=$ $\left\{m, b, h^{3}, \ldots, h^{n}\right\}$; that is, 'A crown $(m)$ and a bracelet $(b)$ both belong to the set Gold, qua proper occurrences of the property gold-ness, along with many others $\left(h^{3}\right.$, $\ldots, h^{n}$ )'. It should be noted that the proper elements $m$ and $b$ of the set Gold are first exclusively defined by their own sole property which is here described; that is, goldness, and not otherwise. Crown and bracelet are consequently only proper names of two elements of the set Gold, this latter being here the sole reality (vastusat). Under this perspective-according to which $m$ and $b$ are nothing but gold, although not the very same specimen of gold - the crown and the bracelet, along with all the other elements of the set Gold, turn out to be stricto sensu equivalent ( $E$, tulyatva) occurrences of the same property, hattakatva. On the model of P2.§2, formulae [8][11], it might thus be stated that:

\begin{abstract}
$\left.\left[50_{\mathrm{b}}\right]\left(b . h_{t}\right\urcorner \boldsymbol{E}\left\llcorner\left(m \cdot h_{t}\right)\right)\right\urcorner \mathbb{N}\left\llcorner\left(\geq 2{ }_{t}\right)\right.$
yat paryāptitvam tulyatvāvacchinnam tad dvitvādi-nirūpitam, etad eva tulyatvam ca kațaka-niștha-hātakatva-avacchinnam mukuṭa-nișța-hātakatvanirūpitam ca; ${ }^{(t)}$ 'A bracelet and a crown are equivalent occurrences of the property gold-ness'; iff $(m \neq b) \wedge\left((m, b) \in\left(\left|h_{t}\right|=\mathrm{H}\right)\right) \wedge \operatorname{card}(\mathrm{H}) \geq 2$; that is, 'A bracelet and a crown are distinct occurrences of gold-ness, thereby they both belong to the set Gold, which in turn must have a cardinality at least equal to two'.
\end{abstract}

The hypothesis under consideration-while aiming at expanding the provisional result according to which there is no difference, that is, mutual exclusion, between bracelet and crown, since only gold is real (vastusat) - entails, as an unintended consequence (prasainga), the obliteration (a-pratibhāsana) of every concurrent property. Thereby, every occurrence of gold-ness ends up with being merely equivalent $(E)$ and consequently indistinguishable ("na bhidyeran") from one another. Assertion [50 ] is undoubtedly true: indeed, a gold bracelet and a gold crown, along with all the other proper elements of the set Gold, are equivalent with respect to the property gold-ness. Nevertheless, once [50 $]$ has been accepted, it does not allow any further distinction within those true occurrences of gold as sole reality. The said occurrences might be then melted, sold or exchanged, observed as incorruptible or resistant to chemical reactions, etc., according to what can be broadly done with gold in its indeterminate aspect. Yet, how could it be possible to identify any different functions or properties of these gold occurrences, such as 
being an artifact, and not a nugget, designed to be put upon the head, and not worn on the wrist? Even though it is an established fact that assertion $\left[50_{b}\right]$ is not false in any respect, it remains no less true that it discards a considerable amount of crucial information. As a rule, in order for a bracelet to be worn as indeed it is, the property bracelet-hood must not be ignored-lest also an ingot be worn on the wrist. Indeed, if the property bracelet-hood never appeared, every possible effect of gold-ness would collapse into the indistinguishableness of the common cause qua sole reality. Consequently, VM notes, we are again pushed back to the original starting point: if there is non-difference with respect to the cause-that is, the gold-yet difference still appears to stand regarding the effects-such as crowns or bracelets. Apropos, VM sharply remarks that:

"in reason of the recurrence (anuvrtti) of the property Being (sattā), which [necessarily] occurs (anugam) in every single existent (sarvavastu) ${ }^{31}$, [if that property were considered solely], there would not be [any possibility] of distinction (vibhāga) [by means of assertions such as] 'This one here, not that one; [or] 'This [appears] in such a manner, not that' ${ }^{32}$, due to the absence of every discriminative (viveka) prover (hetu) concerning any object, anywhere, any time, in any way. In the same manner, in case gold were recognized from

\footnotetext{
${ }^{31}$ In other words, VM proposes here a tautological assertion by virtue of the semantic fitness (yogyatā) of the implied terms. For a discussion regarding sattā, sat and $\sqrt{ }$ as, cf. supra fn. 2-4. Cf. respectively, Quine (1961, p. 23): "No bachelor is married"; Descartes (2011, pp. 61, 68 et passim): "substance corporelle ou étendue", "les choses corporelles ou étendues"; Kant (1998, A7/B11, p. 141): "All bodies are extended [Alle Körper sind ausgedehnt]". Cf. also Heidegger (2014, p. 1; 1990, p. 3): "Why are there beings at all instead of nothing? [Warum ist überhaupt Seisendes und nicht vielmehr Nichts?]".
}

32 Cf. Dharmakīrti (1993, pp. 26-27): 21. naiva kaścit kvacit kathañcidanupalabdho 'pyasadvyavahāravișaya iti cet | sarvasya sarvarūpānām sarvadānivrtteh sarvam sarvatra sarvadā samupayujyeta | idam ca na syāt- 'idam atah', 'nāta idam', 'ihedam', 'iha nedam', 'idānīm idam', 'idānīm nedam', 'idam evam', 'idam naivam' iti; kasyacid api rūpasya kathañcit kvacit kadācid viviktahetor abhāvāt | ananvayavyatirekam viśvam syāt, bhedābhāvāt | avasthānivrttipravrttibhedebhyo vyavastheti cet | nanvata eva sarvavișayasyāsadvyavahārasyābhāvānna te sambhavanti, yatastebhyo vyavasthā syāt $\mid$ kvacid vișaye 'sadvyavahāropagame sa kuta iti vaktavyam | na hy anupalambhādanyo vyavacchedahetur asti; vidhipratiședhābhyam vyavacchede sarvadānupalambhasyaiva sādhanatvāt | anupalambhād eva tadabhyupagame, sa yatraivāsti sarvo 'sadvyavahāravișaya iti vaktavyam, viśeșābhāvāt |; "[A possible objection by a Sānkhya opponent] Nothing is an object of the practice of 'non-existence', whatever it may be and wherever and in whatever way it may remain non-apprehended. [Answer] In that case everything will be applicable everywhere all the time, because every form of everything will remain incessant all the time. Moreover, the following (situations) will not occur-'This (is) out of this'; 'This (is) not out of this'; 'This (is) here'; 'This (is) not here'; 'This (exists) now'; 'This (does) not (exist) now'; 'This (is) of this kind'; 'This (is) not of this kind'. Because there will not be any distinct cause of any (particular) form of any object in any way, anywhere, any time. The universe will be without co-existence and co-absences because there will not be any distinction. [A possible objection:] There will be order (in the universe) on the basis of the distinctions between disappearance and appearance of states (= avastha $)$ (of things). [Answer:] These distinctions themselves are not possible in your system, on the basis of which there will be order; because the practice of non-existence of anything is untenable (according to you). If you accept the linguistic practice of non-existence in the case of some objects, then you will have to tell how that is tenable. Because there is no probans proving non-existence except non-apprehension. When non-existence is proved either on the basis of positive evidence or negative evidence, non-apprehension is always the probans. If one accepts the thesis that it (= the practice of non-existence) is on the basis of non-apprehension only, then one has to say that everything is the object of the practice of non-existence, wherever that (= non-apprehension) is there. Because there is no difference among these cases (in so far as they are cases of non-apprehension)." 
a distance [qua gold solely], then its [possible further] particularizations (viśeșa)—such as earrings, etc.—would not be the object of any desire of knowledge, by reason of their non-difference from gold, which [instead, has already been fully] known". 33

Just like 'Bachelors are unmarried men' and 'All bodies are extended', so sattayā sarvavastūni, or 'By [reason of] Being, every being is [something rather than nothing]'. The property sattā allows us to conclusively identify real beings from unreal ones, such as a hare's horn, but never to distinguish any element within the domain of real, due to the obliteration of every further distinctive property. It follows that defining a golden crown solely as an occurrence of the property satta constitutes, once more, a clear instance of ativyapti; that is, over-application: 'What is a crown?', *'Something existent'. In parallel, with respect to a golden crown qua gold solely, it could be thus improperly concluded that: *hätaka-mukutasya hātakatvavattvam eva asādhāraṇadharmam iti, ato hāțaka-mukuțasya ākaraja-tejodravyavattvam eva asādhāraṇadharmam iti ativyāpti-doṣa-lakșanam; *'Goldness, is the peculiar property defining a golden crown, that is, being a substance of the mineral fire kind; [yet], this is a loose definition, for over-application' ${ }^{34}$

\section{In the Manner of a Conclusion (9)}

Making use of the tools which have been refined in P1\&P2, some significant results have been highlighted here and secured by VM's dialectical spiral movements. Whereas there is no possibility, in VM's view, of instantaneous apparitions (I-Hy) and transformational continua (C-Hy), only permanence tout court (P-Hy) still stands its ground. NN logic has then proved able to escape in its expressions from the conceptual trap of the structural reference to a 'third man' and to be a valid alternative to the standard contemporary logic. Moreover, TKN and DSN have definitively excluded the appeal both to identity and difference-along with all their compromise variations, mediations, coordinations, and juxtapositions-as viable strategies to give an account of the golden crown microsimulation model. As SVN imposes (cf. P1.§4, P2.§4), when we are talking about a golden crown, we are talking about crowns. Everything else is just contradictory. The introduction of the additional label of 'refined definition' (parișkāra-lakșaṇa) in epistemological taxonomy secures the now inescapable truth value of qualified cognition regarding that crown. Therefore, whilst acknowledging that bracelets and crowns have to be correctly known to be properly worn, it can thus be concluded that-in compliance

\footnotetext{
33 VM-B (2018, p. 73): sattānuvrttyā ca sarvavastvanugame "idam iha nedam, idam evam nedam" iti vibhāgo na syāt | "kasyacit kvacit kadācit kathañcid vivekahetor abhāvāt" | api ca dūrāt kanakam ity avagate na tasya kuṇdalādayo viśeșā jijñāsyeran, kanakād abhedāt teșām, tasya ca jñātatvāt I. Cf. Phillips (2012, p. 165): "prover" (hetu).

34 Regarding ativyāpti, cf. supra fn. 7. Regarding the definition of gold as substance and 'mineral fire', cf. $\operatorname{TrS}$ 3, 12 (1951, pp. 8, 54): tatra dravyāṇi pṛthivyaptejovāyvākāśakāladigātmamanāmsi navaiva; "Of them (the seven categories), the Substances are only nine-viz.: earth, water, light [or fire], air, ether, time, space, soul and mind"; ākarajam suvarnāadi; "Gold and such other lustrous metals form the variety [of the objects made of fire] which is dug out of a mine".
} 
with the counterfactual definition of non-difference as expressed in P2.[34]whenever a further property is correctly known as coreferential to another one, although to different levels of generality, the former can no longer be illegitimately obliterated, lest a considerable amount of information become lost and contradictions be generated. This outcome calls for a redefinition of causality and opens new possibilities of complex considerations in which plexuses of properties are involved in the most rigorous non-difference-which will cast new light on the heuristic potential non-dualistic accounts. This is a crucial issue that will need to be handled with great clarity in the last section of this project.

\section{Declarations}

Conflict of interest The author states that there is no conflict of interest.

Open Access This article is licensed under a Creative Commons Attribution 4.0 International License, which permits use, sharing, adaptation, distribution and reproduction in any medium or format, as long as you give appropriate credit to the original author(s) and the source, provide a link to the Creative Commons licence, and indicate if changes were made. The images or other third party material in this article are included in the article's Creative Commons licence, unless indicated otherwise in a credit line to the material. If material is not included in the article's Creative Commons licence and your intended use is not permitted by statutory regulation or exceeds the permitted use, you will need to obtain permission directly from the copyright holder. To view a copy of this licence, visit http:// creativecommons.org/licenses/by/4.0/.

\section{Notation and Abbreviations}

a primitive term (lowercase italics)

$-t \quad$ abstraction functor, expressing the Sanskrit suffix $-t v a$ or $-t \bar{a}$ (e.g., $a_{t}=a-$ hood)

A set A (capital)

$\left|a_{t}\right| \quad$ extension of an abstract; $\left|a_{t}\right|=\mathrm{A}$

$R \quad$ relation $R$ (capital italics)

$\boldsymbol{R} \quad$ relational abstract (bold capital italics)

$R^{\left(R_{\prime}\right)} \quad$ relation $R^{\prime}$ interpreted as $R$, salva veritate

$R[\mathrm{~A}] \quad$ the relation $R$ set of destination; for $R: \mathrm{A} \mapsto \mathrm{B}$, $\operatorname{dom} R \subseteq \mathrm{A}, \operatorname{ran} R \subseteq \mathrm{B}$, and $R[\mathrm{~A}]=\mathrm{B}$

$\neg \quad$ avacchedaka operator; identifying the limitor of a relational abstract

ᄂ $\quad$ nirūpaka operator; identifying the conditioner of a relational abstract

- nistha operator; connecting an abstract to a primitive term

$\rightleftharpoons \quad$ tadviparyayena operator ('vice versa'); expressing a symmetrical relation

Iई yathā-tath $\bar{a}$ operator ('just like-so'); capable of expressing the coordination of a relation with its inverse $\left(R \wedge R^{-1}\right)$. It always preserves the distinction between abstract properties and primitives terms of the anuyogin and pratiyogin positions

${ }^{*} \varphi \quad$ 'It is false that $\varphi$ '

(t) ‘...' tātparya (purport of an expression)

DSN Dharma-Sāmānādhikaranya-Naya ('Properties Coreference Rule') 


\section{SVN Samānādhikaraṇa-Viśiștatva-Nyāya ('Principle of Coreferential Qualification') \\ TKN Tādātmìya-Kāraṇa-Naya ('Identity Reduction Rule') \\ TvN Tadvattva-Nyāya ('Axiom of Possession')}

\section{References}

\section{Sanskrit Texts}

Amalānanda (1895). Vedāntakalpataru. R. Tailaṅga (ed.). Vizianagram Sanskrit Series, Vol XI, Part I. Benares: E.J. Lazarus \& Co.

BSBh - (1960). Brahmasūtra Shānkarabhāshya. Bādarāyaṇa's Brahmasūtras with Shankarāchārya's Commentary. Translated into English by V.M. Apte. Bombay: Popular Book Depot.

BSBhB — Bhāskarāchārya (1991). Brahmasūtra with a Commentary of Bhāskarāchārya. Vindhyeśvarī Prasāda Dvivedin (ed.). Varanasi: Chowkhamba Sanskrit Series Office.

BSBh - (2018) [1980]. Brahmasūtraśāmkarabhāṣya with the Commentaries: Bhāṣaratnaprabhā of Govindānanda, Bhāmatī of Vācaspati Miśra, Nyāyanirnaya of Ānandagiri. Shastri, J.L. (ed.). Delhi: Motilal Banarsidass.

Dharmakīrti (1993). Vādanyāya of Dharmakīrti. The Logic of Debate. P.P. Gokhale (ed.). Bibliotheca Indo-Buddhica Series, 126. Delhi : Sri Satguru Publications.

Dharmarāja Adhvarin (1942). Vedānta Paribhāṣā. S.S. Sūryanārāyaṇa Śāstri (ed.). Adyar: Adyar Library.

Gadādhara Bhațāāārya (1929), Śaktivāda, with the Vivrti Commentary by Paṇịt Pravara Śrī Harīnātha Tarka Siddhānta Bhatțācarya. Edited with critical notes by Goswami Damodar Śastri. Benares: Chowkhamba, Kāshi Sanskrit Series, n. 77.

Mandana Miśra (1937). Brahmasiddhi with Commentary of Śankapāṇi. Kuppuswami Śastri S. (ed.). Madras: Madras Government Oriental Manuscripts Series, Government Press.

Maṇụana Miśra-G. Brahmasiddhi. (GRETIL) Göttingen Register of Electronic Texts in Indian Languages. Based on the ed. by Kuppuswami Śastri S. (1937). Input by Diwakar Acharya 1999-2003. http://gretil.sub.uni-goettingen.de/gretil/corpustei/transformations/html/sa_mandana mizra-brahmasiddhi.htm.

Nāgārjuna (1999) [1986]. Mūlamadhyamakakāririkā of Nāgārjuna. The Philosophy of the Middle Way. Kalupahana, D.J. (ed). Delhi: Motilal Banarsidass.

NK (1928) — Jhalakīkar, M.B. Nyāyakośa or Dictionary of Technical Terms of Indian Philosophy. Poona: Bhandakar Oriental Research Institute.

NS (2009) — Le Nyāya-Sūtra de Gautama Akșapāda. Le Nyāya-Bhāṣya d'Akșapāda Pakșilasvāmin. L'art de conduire la pensée en Inde ancienne. Édition, traduction et présentation de Michel Angot. Paris: Les Belles Lettres.

NSM [Nyāya-siddhānta-muktāvalī] — Bhațțācārya, Viśvanāthapañcānana (1988) [I ed. Madras 1923]. Kārikāvalī muktāvalīsahitā sā ca prabhāmañjūṣādinakarīrāmarudrīgañgārāmīti vyākhyāpañcakasamanvitā. C. Śañkararāma Śāstrī (ed.). Vārāṇasī: Caukhambā Saṃskṛta Pratișthāna.

Pāṇ. - Pāṇini (1999). The Aștâadhyāyyà of Pāṇini. Sharma, R. N. (ed.). Vol. IV. Delhi: Munshiram Manoharlal Publishers Pvt. Ltd.

Prakāsāatman (1892). Pañcapādikāvivaraṇa of Prakāśātman with extracts fromthe Tattvadīpana and Bhāvaprakāśikā. R.S. Bhagavatācārya (ed.). Vizianagram Sanskrit Series (No. 5). Benares: E.J. Lazarus \& Co.

Praśastapāda (1994) Word Index to the Praśastapādabhāṣya. A complete word index to the printed editions of the Praśastapādabhāsya. J. Bronkhorst, Yves Ramseier (eds.). Delhi: Motilal Banarsidass.

SK - (1934) Īśvarakṛṣna, Sāṃkyakārikā. In The Tattva-Kaumudī. Vācaspati Miśra's Commenary on the Sāṃkhya-kārikā. Jha, G., Sharma, H.D., Patkar, M.M. (eds.). Poona: The Oriental Book Agency.

TCM (2006) [1966] — Gaingeśa, Tattvacintāmani. Gaingeśa's Theory of Truth. Containing the Text of Gañgeśa’s Prāmānya (jñapti) vāda. Mohanty, J.N. (ed.). 2nd ed. Delhi: Motilal Banarsidass. 
TCM (2009) - Gañgeśa, Tattvacintāmaṇi. Epistemology of Perception. Pratyakșa-khaṇda. The Perception Chapter. Phillips S.H., Ramanuja Tatacharya N.S. (eds.). Delhi: Motilal Banarsidass.

TrS - Annaṃbhațta (1930). Tarkasamgrahah of Annambhațta with the Author's own Dīpika and Govardhana's Nyāya-bodhini. Y.V. Athalye, M.R. Bodas (eds.). Bombay: Bombay Sanskrit Series; n. LV.

TrS - Annambhațta (1951) [1932]. Tarkasamgrahah. A Primer of Indian Logic. M. V. Kuppuswami Śāstri (ed.). Mylapore, Madras: The Kuppuswami Śāstri Research Institute.

TrS — Annaṃbhațta (2007) [II ed.]. Tarkasamgrahah nyāyabodhini-padakrtya-dīpikā-kiranāvalīvyākhyopetah. Saṃpādakạ̣ Śrīkṛ̦ṇavallabhācārya. Vārāṇasī: Caukhambā Vidyābhavana.

Upanișad. In: Olivelle, P. (1998). The Early Upanișads. Annotated Text and Translation. Oxford: Oxford University Press.

VM-B (1933) - Vācaspati Miśra. The Bhāmatī of Vācaspati on Śankara Brahmasūtrabhāṣya (Catussūtrī). Edited with an English Translation by S.S. Suryanarayana Śāstrī and C. Kunhan Raja. Madras: Adyar.

VM-B (2018) - Vācaspati Miśra, Bhāmatī; cf. BSBh (2018).

VM-B - Göttingen Register of Electronic Texts in Indian Languages (GRETIL). Vācaspati Miśra: Bhāmatī; subcomm. on Samkara's Brahmasūtrabhāsya, text without sūtras; input by members of the Sansknet Project. URL: http://gretil.sub.uni-goettingen.de/gretil/1_sanskr/6_sastra/3_phil/vedanta/ vacbhamu.htm. Georg-Augustus Universität, Göttingen. Retrieved: 2021.

VM-T - Vācaspati Miśra (1896). An English Translation with the Sanskrit Text of the Tattvakaumudī of Vācaspati Miśra. G. Jha (ed.). Bombay: Tattva-vivechaka Press. VM-T (1934) The Tattva-Kaumudī. Vācaspati Miśra's Commenary on the Sāmnkhya-kārikā. Jha, G., Sharma, H.D., Patkar, M.M. (eds.). Poona: The Oriental Book Agency.

VM-TS (2006) - Vācaspatimiśra's Tattvasamīkșā, the earliest commentary on Mandanamiśra's Brahmasiddhi. Diwakar Acharya (ed.); Stuttgart: Franz Steiner.

VS — Kanāda (1923). The Vaiśeșika Sütra of Kanāda. Basu, B.D., Sinha, N., (eds.). 2nd ed. Allahabad: The Pānini Office, Bhuvaneśwarī Āśrama.

VVR (2000) [1934] - Bhāskararāya. Varivasyāraharasya and its Commentary Prakāśa by Śr̄ Bhāskararāya Makhin. S. Subrahmanya Śāstrī (ed.). Madras: Adyar Library and Research Centre.

\section{Other Texts}

Agrawal, M. M., \& Potter, K. (eds.). (2013). Bhedābheda and Dvaitādvaita Systems. The Encyclopedia of Indian Philosophies. Vol. XV. Delhi: Motilal Banarsidass.

Anrò, A. (2021). 'Nothing But Gold. Part 1. Complexities in Terms of Non-difference and Identity'. Journal of Indian Philosophy, 49, 361-386. https://doi.org/10.1007/s10781-021-09463-4

Anrò, A. (2021). 'Nothing but Gold: Complexities in terms of Non-difference and Identity. Part 2. Contrasting Equivalence, Equality, Identity, and Non-difference'. Journal of Indian Philosophy, 49, 387-420. https://doi.org/10.1007/s10781-021-09464-3

Anro, A. (2022). 'Nyāya formalized. exercises of application'; Philosophy East \& West, Volume 72, Number 1 January 2022, 1-34.

B (1879-1889) — Böhtlingk, O. Sanskrit-Wörterbuch. St. Petersburg: Buchdruckerei der Kaiserlichen Akademie der Wissenschaften.

Bhattacharyya, S. (1987). Some aspects of the Navya-Nyāya theory of inference. In J. Ganeri (ed.) (2001). Indian logic. A reader (pp. 162-182). Richmond: Curzon.

Dasgupta, S. (1961) [1949]. A history of Indian philosophy. Vol. IV. Indian pluralism. Cambridge: Cambridge University Press.

Descartes, R. (2011) [1641]. In M. Beyssade, J.-M. Beyssade (Eds.), Méditations métaphysiques: Objections et réponses suivies de quatre lettres. Flammarion.

Glare, P. G. W. (Ed.). (1968). Oxford latin dictionary. Oxford University Press.

Goodman, N. (1977) [1951]. The structure of appearance; 3rd ed. Reidel Publishing Company.

Grimes, J. (1996). A concise dictionary of Indian philosophy. State University of New York Press.

Guha, D. C. (1979). Navya-Nyāya system of logic. Basic theories and techniques. Motilal Banarsidass. 
Halbfass, W. (1992). On being and what there is. Classical Vaiśeșika and the history of Indian ontology. State University of New York Press.

Heidegger, M. 1977 [1927]. Sein und Zeit. Gesamtausgabe 2. Klostermann.

Heidegger, M. (2014) [2000]. Introduction to metaphysics. In G. Fried, G. Polt (eds.), Second Edition. New Haven \& London: Yale University Press. Id. (1990) [1935], Einführung in die Metaphysik, Gesamtausgabe, 40. Frankfurt am Main: Klostermann.

Ingalls, D. H. H. (1951). Materials for the study of Navya-Nyāya logic. Motilal Banarsidass.

Jha, V. N. (2001). Dictionary of Nyāya terms. University of Pune: Centre of Advanced Studies in Sanskrit.

Kant, I. (1998) [1781-1787]. In P. Guyer, A. W. Wood (Eds.), Critique of Pure Reason [Kritik der reinen Vernunft]. Cambridge University Press.

KŚ - Kuppuswami Śāstri, see TrS(1951)

Matilal, B. K. (1968). The Navya-Nyāya Doctrine of Negation. The semantic and ontology of negative statements in Navya-Nyāya philosophy. Harvard University Press.

McDermott Senape, A.C. (1969). An eleventh-century Buddhist logic of 'exists'. Ratnakīrti's Kṣaṇabhangasiddhih Vyatirekātmikā. D. Reidel Publishing Company.

MW (1899) - Monier-Williams, M. A Sanskrit-English Dictionary: Etymologically and philologically arranged with special reference to cognate Indo-European languages. Oxford: Clarendon.

Larson, G. J. (1988) [1969]. Classical Samkhya: An interpretation of its history and meaning. Delhi: Motilal Banarsidass.

Lee, J. M. (1973). The form of a reductio ad absurdum. Notre Dame Journal of Formal Logic, 14, 381386.

Partridge, E. (1966). Origins. A short etymological dictionary of modern English. Routledge.

Pellegrini, G. (2016). 'Differentiating jāti and upadhi: towards a further exegesis of the six jatibädhakas according to Navya-Nyāya. In Proceedings of the Meeting of the Italian Association of Sanskrit Studies (Bologna 27-28 March 2015). Edited by Torella R. et als. Rivista degli Studi Orientali. PisaRoma: Fabrizio Serra Editore: Suppl. n², vol. LXXXIX, 73-92.

Phillips, S. H. (1997). Classical Indian Metaphysics. Refutation of Realism and the Emergence of 'New Logic'. Routledge.

Phillips, S. H. (2012). Epistemology in classical India. The knowledge sources of the Nyāya schools. Motilal Banarsidass.

Potter, K. H. (1977). Indian metaphysics and epistemology. The tradition of Nyāya-Vaiśeșika up to Gangeśa. The encyclopedia of Indian philosophies. Vol. II. Motilal Banarsidass.

Quine, W. V. O. (1961) [1953]. 'Two dogmas of empiricism'; originally published in The philosophical review 60 (1951): 20-43. In Id., From a Logical Point of View. Harvard University Press.

Ranganath, S. (1999). Contribution of Vācaspati Miśra to Indian Philosophy. Pratibha Prakashan.

Renou, L. (1957). Terminologie grammaticale du Sanskrit. Vol. I. Bibliothèque de 1'Ecole des hautes études n. 280. Honoré Champion Editeur.

Shaw, J. L. (1987). The Nyāya on double negation. Notre Dame Journal of Formal Logic, 29(1), 139-154. Whitehead, A. N., \& Russell, B. (1910). Principia Mathematica (Vol. I). Cambridge University Press.

Publisher's Note Springer Nature remains neutral with regard to jurisdictional claims in published maps and institutional affiliations. 